\title{
Catalysis of linear alkene metathesis by Grubbs-type ruthenium alkylidene complexes containing hemilabile $\alpha, \alpha-$ diphenyl-(monosubstituted-pyridin-2-yl)methanolato ligands
}

\author{
Tegene T. Tole ${ }^{1,2}$, Johan H. L. Jordaan ${ }^{1}$ and Hermanus C. M. Vosloo*1
}

\author{
Full Research Paper \\ Address: \\ ${ }^{1}$ Research Focus Area for Chemical Resource Beneficiation, \\ Catalysis and Synthesis Research Group, North-West University, \\ Hoffmann Street, 2531 Potchefstroom, South Africa and ${ }^{2}$ Department \\ of Chemistry, College of Natural and Computational Sciences, \\ Hawassa University, Hawassa, Ethiopia \\ Email: \\ Hermanus C. M. Vosloo* - manie.vosloo@nwu.ac.za \\ * Corresponding author \\ Keywords: \\ Grubbs-type precatalyst; hemilabile; 1-octene metathesis; \\ pyridinyl-alcoholato ligand
}

Beilstein J. Org. Chem. 2019, 15, 194-209. doi:10.3762/bjoc. 15.19

Received: 02 September 2018

Accepted: 21 December 2018

Published: 22 January 2019

This article is part of the thematic issue "Progress in metathesis chemistry III".

Guest Editors: K. Grela and A. Kajetanowicz

(c) 2019 Tole et al.; licensee Beilstein-Institut. License and terms: see end of document.

\begin{abstract}
Four new Grubbs-type precatalysts $\left[\mathrm{RuCl}\left(\mathrm{H}_{2} \mathrm{IMes}\right)\left(\mathrm{O}^{\wedge} \mathrm{N}\right)(=\mathrm{CHPh})\right]$, where $\left[\mathrm{O}^{\wedge} \mathrm{N}=\alpha\right.$, $\alpha$-diphenyl-(3-methylpyridin-2yl)methanolato, $\alpha, \alpha$-diphenyl-(4-methylpyridin-2-yl)methanolato, $\alpha, \alpha$-diphenyl-(5-methylpyridin-2-yl)methanolato and $\alpha, \alpha$ diphenyl-(3-methoxypyridin-2-yl)methanolato] were synthesized and tested for their activity, stability and selectivity in the 1 -octene metathesis reaction. Overall the precatalysts showed good activity and high stability for the metathesis of 1-octene at temperatures above $80{ }^{\circ} \mathrm{C}$ and up to $110^{\circ} \mathrm{C}$. Selectivities towards the primary metathesis products, i.e., 7-tetradecene and ethene, above $85 \%$ were obtained with all the precatalysts at 80 and $90{ }^{\circ} \mathrm{C}$. High selectivities were also observed at $100{ }^{\circ} \mathrm{C}$ for the $4-\mathrm{Me}$ - and 3-OMe-substituted precatalysts. With an increase in temperature an increase in isomerisation products and secondary metathesis products were observed with the latter reaching values $>20 \%$ for the 3-OMe- and 3-Me-substituted precatalysts at 110 and $100{ }^{\circ} \mathrm{C}$, respectively. All the precatalysts exhibits first-order kinetics at $80^{\circ} \mathrm{C}$ with the 3 -substituted precatalysts the slowest. The behaviour of the 3 -substituted precatalysts can be attributed to electronic and steric effects associated with the adjacent bulky phenyl groups.
\end{abstract}

\section{Introduction}

The alkene metathesis reaction is now well established as a powerful synthetic tool in organic and polymer chemistry [1,2]. The development of metal alkylidene precatalysts based on ruthenium, starting with the so-called Grubbs 1 (1) and 2 (2) metal carbenes, played a major role to extend the versatility of the reaction including the application of these in industrial processes (Figure 1). Of course, the role of the so-called Schrock metal carbenes based on tungsten and molybdenum should not be ignored in the success story of the alkene metathesis reaction but it is not the focus of this article. 


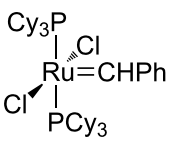

1

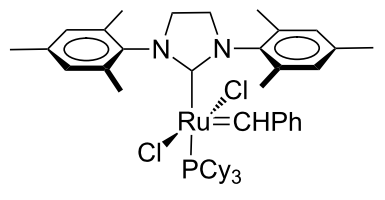

Figure 1: Structures of Grubbs 1 (1) and 2 (2) precatalysts.

The large number of ruthenium alkylidene precatalysts that has been developed is based on the design concepts illustrated in Scheme 1 [3]. The design concept $\mathbf{C}$ is of interest because of the potential hemilabile nature and latent metathesis activity of these complexes [4]. Of particular interest to us are the ruthenium alkylidene complexes containing the pyridinyl alcoholato bidentate ligands investigated by a number of research groups [5].

$$
\mathrm{Cl}_{\mathrm{L}^{2}}^{\mathrm{R}_{\mathrm{L}}^{\mathrm{L}}=\mathrm{Cl}} \mathrm{CHR}
$$

A

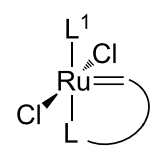

B<smiles>[R]C[R]([Al])(Cl)Cl</smiles>

c<smiles>[R][Ca][Te]([3H])(Cl)Cl</smiles>

D
$L^{1}=P R_{3}, H_{2} I M e s ; L^{2}=P R_{3}$

Scheme 1: Design concepts for ruthenium alkylidene precatalysts [3]. diethyl diallylmalonate with $100 \%$ conversion after $30 \mathrm{~min}$, results comparable to the unimolecular catalyst.

Denk et al. [9] synthesised $N$-heterocyclic (NHC) ruthenium alkylidene complexes containing pyridinyl-alcoholato ligands (4). These complexes were tested as precatalysts at different temperatures in the ROMP of norbornene and cyclooctene. Oligomers were obtained at room temperature in the presence of $4 \mathbf{a}$ and $\mathbf{4 d}$, while $\mathbf{4 b}$ and $4 \mathbf{c}$ yielded polymers. At $60{ }^{\circ} \mathrm{C}$, ROMP was observed with norbornene (98-100\%) and cyclooctene (72-80\%) in the presence of 4 .

We investigated a number of Grubbs 1- and Grubbs 2-type (5) metal carbenes with pyridinyl alcoholato ligands for the 1-octene metathesis reaction (Figure 3) [10-14]. The incorporation of pyridinyl-alcoholato ligands in the Grubbs-type precatalysts has shown an increase in the thermal stability, activity and lifetime of the precatalysts when compared to 1 and $\mathbf{2}$ [10]. The pyridinyl-alcoholato Grubbs 2-types exhibited higher activities and selectivities than the Grubbs 1-types and were investigated in more detail. It is clear from the results that the chelating ability of the pyridinyl alcoholato ligands combined with the NHC ligand is responsible for the activity and improved stability of the precatalyst at high temperatures. In general $\mathbf{5 d}$ performed the best in the 1-octene metathesis reactions when compared to complexes $\mathbf{5 a}-\mathbf{c}$ and $\mathbf{5 e - h}$. The catalytic perfor-

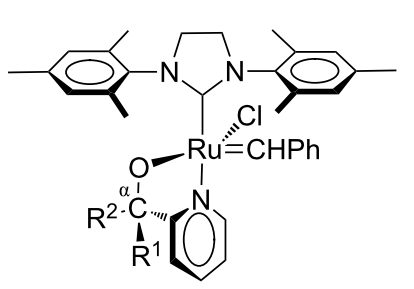
5a, $\mathrm{R}^{1 / 2}=-\left(\mathrm{CH}_{2}\right)_{5}^{-}$
5b, $R^{1}=R^{2}=M e$
5c, $R^{1}=R^{2}=i P r$
5d, $R^{1}=R^{2}=P h$
5e, $\mathrm{R}^{1}=\mathrm{R}^{2}=\mathrm{H}$
5f, $\mathrm{R}^{1}=2-\mathrm{MePh}, \mathrm{R}^{2}=\mathrm{Ph}$
5g, $R^{1}=2-M e P h, R^{2}=M e$
5h, $R^{1}=\mathrm{Ph}, \mathrm{R}^{2}=\mathrm{iPr}$
$5 i, R^{1}=2-C I P h, R^{2}=P h$
$5 j, R^{1}=4-C I P h, R^{2}=P h$
5k, $\mathrm{R}^{1}=4-\mathrm{OMe}, \mathrm{R}^{2}=\mathrm{Ph}$

Figure 3: Structures of Grubbs 2-type (5) pyridinyl-alcoholato precatalysts.

[8]. These complexes catalysed the RCM reaction (at $80^{\circ} \mathrm{C}$ ) of

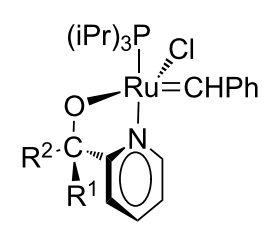

3
3a, $\mathrm{R}^{1}=\mathrm{R}^{2}=\mathrm{Ph}$
3b, $R^{1}=R^{2}=M e$
3c, $R^{1}=P h, R^{2}=M e$
3d, $\mathrm{R}^{1}=\mathrm{R}^{2}=p-\mathrm{CIPh}$
3e, $\mathrm{R}^{1}=\mathrm{R}^{2}=p-\mathrm{NMe}_{2} \mathrm{Ph}$
3f, $\mathrm{R}^{1}=\mathrm{R}^{2}=p-(t-\mathrm{Bu}) \mathrm{Me}_{2} \mathrm{SiOPh}$

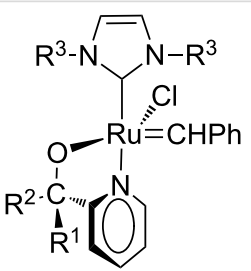

4a, $\mathrm{R}^{1 / 2}=-\left(\mathrm{CH}_{2}\right)_{5^{-}}, \mathrm{R}^{3}=\mathrm{Cy}$

4b, $\mathrm{R}^{1 / 2}=-\left(\mathrm{CH}_{2}\right)_{5^{-}}, \mathrm{R}^{3}=\mathrm{PhEt}$

4c, $R^{1}=R^{2}=M e, R^{3}=C y$

4d, $R^{1}=R^{2}=M e, R^{3}=$ PhEt

Figure 2: Structures of Grubbs 1-type (3) and 2-type (4) pyridinyl-alcoholato precatalysts. 
mance could be further tuned by the incorporation of an electron-donating (e.g., OMe, 5k) or electron-withdrawing (e.g. Cl, $\mathbf{5 i}$ and $\mathbf{5 j}$ ) group at the 2- or 4-position of one of the $\alpha$-phenyl groups of 5d [14]. At $80-110{ }^{\circ} \mathrm{C}$ these complexes showed improved catalytic performance in the metathesis of oct-1-ene. At $110{ }^{\circ} \mathrm{C}$ complex $\mathbf{5 k}$, with $96 \%$ conversion and $95 \%$ selectivity towards the primary metathesis products tetradec-7-ene and ethene, outperformed the other complexes. In a computational study the improved catalytic performance was attributed to strengthening of the $\mathrm{Ru}-\mathrm{N}$ bond due to steric repulsion between the substituted phenyl group and the NHC ligand [14]. An 8-quinolinolate Grubbs 2-type derivative, patented by Slugove and Wappel [15] for use in ROMP reactions, was found to be inactive $(<1 \%$ conversion) for 1 -octene metathesis at $60{ }^{\circ} \mathrm{C}[12]$.

Schachner et al. [16] evaluated the catalytic activity of $\mathbf{5 b}, \mathbf{5 d}$ and related complexes for the ROMP of cyclooctene, CM of hex-5-enyl acetate with dec-5-ene and the RCM of hex-5-en-1yl undec-10-enoate. Superior (CM, RCM) to moderate (ROMP) activities were observed for most of these precatalysts. An interesting result was the very high affinity ("stickiness") to untreated, unmodified and commercially available chromatography-grade silica. This was exploited further by Cabrera et al. $[17,18]$ when $\mathbf{5 b}$ and related complexes were investigated as heterogeneous precatalysts in biphasic RO-RCM and CM reactions. The substrate and catalyst were adsorbed on a thin layer silica plate and developed in EtOAc/hexane $(1: 7 \mathrm{v} / \mathrm{v})$ for the $\mathrm{CM}$ of methyl 9-dodecene and in hexane for the RO-RCM of cis-cyclooctene.

The above-mentioned studies clearly illustrate the versatility and use of ruthenium alkylidene complexes with pyridinyl-alcoholato ligands. In principle these studies had one approach in common concerning the pyridinyl-alcoholato ligand, and that was to focus on substituents on the $\alpha$-carbon of the ligand. To our knowledge, there are no reports on investigations of electronic and/or steric effect(s) of pyridinyl substituents on the chelation efficiency of pyridinyl alcoholato ligands, and subsequently its metathesis activity. Therefore, in this paper, we investigated the influence of a monosubstituent on the pyridinyl moiety on the 1-octene metathesis activity of a Grubbs 2-type precatalyst with an $\alpha, \alpha$-diphenyl methanolato ligand. For the synthesis of the pyridinyl methanol compounds, commercially available substituted bromopyridines were reacted with benzophenone followed by a reaction of the lithiated alcohol with 2 . Four new ruthenium alkylidene complexes, i.e., 6-9 (Figure 4), were successfully obtained and investigated as precatalyst in 1 -octene metathesis in the temperature range $40-110^{\circ} \mathrm{C}$. The stability, selectivity and turnover frequency (TOF) of 2 increased upon substituting Me and OMe groups on the various positions of the pyridine ring of the pyridinyl-alcoholato ligands at high temperatures $\left(80-110^{\circ} \mathrm{C}\right)$. The increase in stability is attributed to the electronic and steric influence of the Me and OMe groups on $\mathrm{Ru}-\mathrm{N}$ chelation. The activity of the precatalysts also showed a significant improvement upon increasing the reaction temperature from 40 to $110{ }^{\circ} \mathrm{C}$. The increase in the activity of the precatalysts is relatively low in the $40-60{ }^{\circ} \mathrm{C}$ range, but a high activity difference is observed upon increasing the temperature in $10^{\circ} \mathrm{C}$ intervals between 70 and $110^{\circ} \mathrm{C}$.

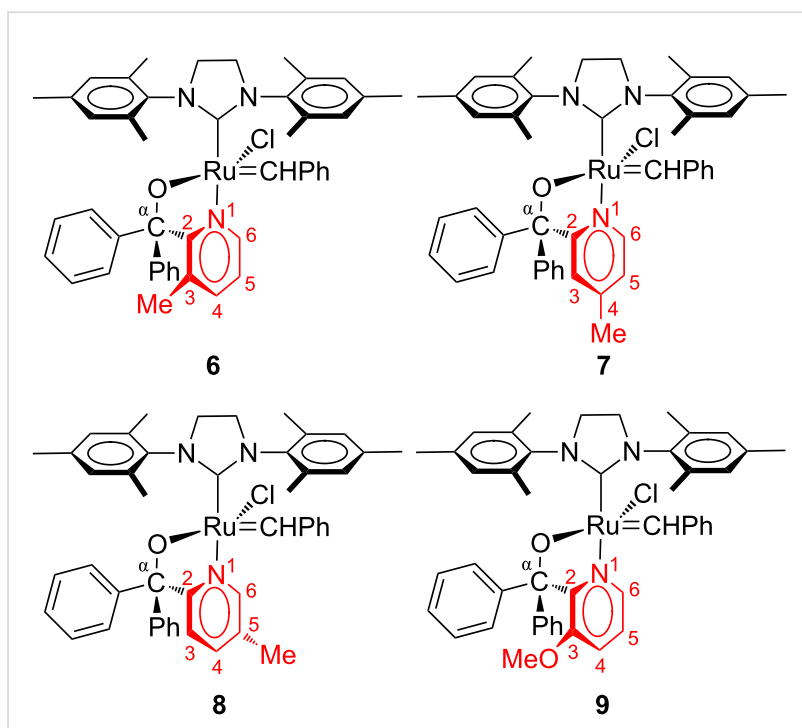

Figure 4: Structures of pyridinyl-substituted Grubbs 2-type pyridinylalcoholato precatalysts.

\section{Results and Discussion}

A mixture of products, summarised in Table 1, is obtained during the metathesis of 1-octene, i.e., primary metathesis products (PMPs), isomerisation products (IPs) and secondary me-

\begin{tabular}{|c|c|c|c|}
\hline Reaction & Substrate ${ }^{a}$ & Products $^{a}$ & Abbrev. \\
\hline primary metathesis & & & PMPs \\
\hline self-metathesis & $\mathrm{C}=\mathrm{C}_{7}$ & $\mathrm{C}=\mathrm{C}+\mathrm{C}_{7}=\mathrm{C}_{7}$ & \\
\hline isomerisation & $\mathrm{C}=\mathrm{C}_{7}$ & $\begin{array}{l}\mathrm{C}_{2}=\mathrm{C}_{6}+ \\
\mathrm{C}_{3}=\mathrm{C}_{5}+ \\
\mathrm{C}_{4}=\mathrm{C}_{4}\end{array}$ & IPs \\
\hline $\begin{array}{l}\text { secondary } \\
\text { metathesis }\end{array}$ & & & SMPs \\
\hline cross metathesis & $\begin{array}{l}\mathrm{C}=\mathrm{C}_{7}+ \\
\mathrm{C}_{2}=\mathrm{C}_{6}\end{array}$ & $\begin{array}{l}\mathrm{C}_{2}=\mathrm{C}_{7}+ \\
\mathrm{C}=\mathrm{C}_{6}+\mathrm{C}=\mathrm{C}_{2} \\
+\mathrm{C}_{6}=\mathrm{C}_{7}\end{array}$ & \\
\hline self-metathesis & $\mathrm{C}_{2}=\mathrm{C}_{6}$ & $\begin{array}{l}\mathrm{C}_{2}=\mathrm{C}_{2}+ \\
\mathrm{C}_{6}=\mathrm{C}_{6}\end{array}$ & \\
\hline
\end{tabular}

${ }^{\mathrm{a} G e o m e t r i c a l ~ i s o m e r s ~ a n d ~ h y d r o g e n s ~ a r e ~ n o t ~ s h o w n ~ f o r ~ s i m p l i c i t y . ~}$ 
tathesis products (SMPs). The PMPs, 7-tetradecene (cis and trans) and ethene, forms as a result of the self-metathesis (SM) of 1-octene. Simultaneously 1-octene is isomerised to 2-, 3- and 4-octene (IPs). The subsequent SM and CM reactions of the internal alkenes yield alkenes (cis and trans) in the $\mathrm{C}_{3}-\mathrm{C}_{13}$ range (SMPs).

All the reactions were followed by GC at regular sampling intervals until $540 \mathrm{~min}$. Because the observed formation of IPs is mostly below $2 \%$ and never above $4 \%$ it is also not shown in the figures.

\section{Effect of the reaction temperature}

The results of the metathesis of 1-octene at temperatures $40-100{ }^{\circ} \mathrm{C}$ are presented in Figure 5 and Table 2 for precatalyst 7. The rate of self-metathesis of 1-octene showed an increase upon raising the reaction temperature from 40 to $100^{\circ} \mathrm{C}$. The metathesis reaction is insignificant at lower temperatures (40 to $60{ }^{\circ} \mathrm{C}$ ). Upon raising the temperature beyond $70^{\circ} \mathrm{C}$, an increase in the reaction rate was observed, resulting in a significant increase in 1-octene conversion greater than $80 \%$ at $90{ }^{\circ} \mathrm{C}$ after $540 \mathrm{~min}$. Increasing the temperature further to $100{ }^{\circ} \mathrm{C}$ showed a dramatic increase in the metathesis reaction rate and a high PMPs formation are observed at $100{ }^{\circ} \mathrm{C}(>85 \%$ after ca. $200 \mathrm{~min}$ ).

The formation of PMPs did not equilibrate within $540 \mathrm{~min}$ for the temperature range 50 to $80{ }^{\circ} \mathrm{C}$; however, its formation equilibrated at ca. $400 \mathrm{~min}$ at $90{ }^{\circ} \mathrm{C}$ and ca. $200 \mathrm{~min}$ at $100{ }^{\circ} \mathrm{C}$. This shows that 7 is stable at high temperatures, with moderate to very good PMPs (ca. 25-80\%) formation. On the other hand, the formation of SMPs (ca. $0.2-2.0 \%$ ) and IPs (ca. $0.2-0.5 \%$ ) is negligible in the range $40-80{ }^{\circ} \mathrm{C}$, while a more significant amount is formed at temperatures greater than $90{ }^{\circ} \mathrm{C}$ (ca. $10-14 \%$ SMPs and $1.7-2.1 \%$ IPs) after $540 \mathrm{~min}$.

Table 2 summarises the overall catalytic performance of 7 at 420 min. In this period it can be seen that the PMPs and SMPs formation, TON, and TOF of the precatalyst show a direct relationship with temperature. The highest PMPs formation is observed for the temperature changes from 80 to $90{ }^{\circ} \mathrm{C}(29.3 \%)$ and the least for 40 to $50{ }^{\circ} \mathrm{C}(0.7 \%)$ at $420 \mathrm{~min}$.

The selectivity towards PMPs showed a dramatic increase upon increasing the temperature from 40 to $80{ }^{\circ} \mathrm{C}(23-97 \%)$; however, it showed a decrease going from $80(97 \%)$ to $90^{\circ} \mathrm{C}(89 \%)$,

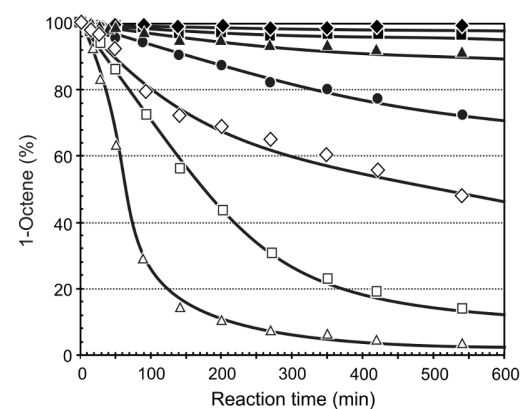

(a)

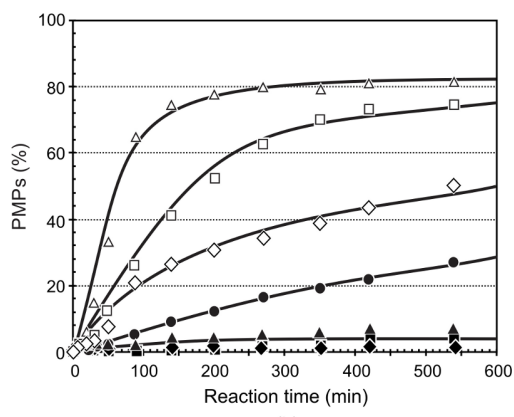

(b)

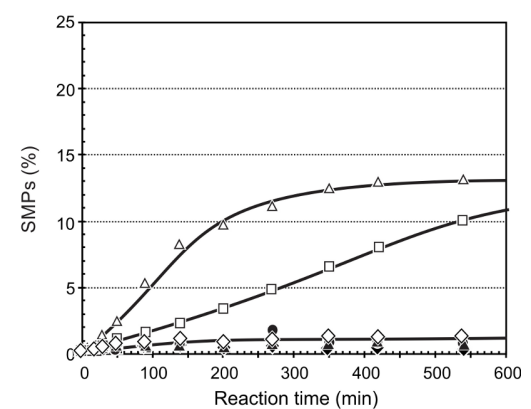

(c)

Figure 5: The influence of the reaction temperature on the (a) conversion of 1-octene, (b) formation of PMPs and (c) formation of SMPs using precatalyst $7(\mathrm{Ru} / 1$-octene $=1: 9000)$. $\left[\bullet 40^{\circ} \mathrm{C}, \square 50^{\circ} \mathrm{C}, \Delta 60^{\circ} \mathrm{C}, \bullet 70^{\circ} \mathrm{C}, \diamond 80^{\circ} \mathrm{C}, \square 90^{\circ} \mathrm{C}, \Delta 100{ }^{\circ} \mathrm{C}\right]$.

Table 2: Summary of the catalytic performance of precatalyst 7 at different temperatures (Ru/1-octene molar ratio 1:9 000, 420 min).

\begin{tabular}{|c|c|c|c|c|c|c|c|c|}
\hline Entry & Temp. $\left[{ }^{\circ} \mathrm{C}\right]$ & Conv. ${ }^{a}$ & $\mathrm{PMPs}^{\mathrm{a}}$ & $\mathrm{SMPs}^{\mathrm{a}}$ & $\mathrm{IPs}^{\mathrm{a}}$ & $\mathrm{s}^{\mathrm{b}}$ & $\mathrm{TON}^{\mathrm{C}}$ & TOF $^{d}$ \\
\hline 1 & 40 & 0.8 & 0.2 & 0.2 & 0.4 & 23 & 18 & $0.07 \times 10^{-2}$ \\
\hline 2 & 50 & 2.1 & 0.9 & 0.4 & 0.8 & 44 & 81 & $0.32 \times 10^{-2}$ \\
\hline 3 & 60 & 7.2 & 5.8 & 1.1 & 0.3 & 80 & 522 & $2.07 \times 10^{-2}$ \\
\hline 4 & 70 & 22.3 & 21.2 & 0.9 & 0.2 & 95 & 1908 & $7.57 \times 10^{-2}$ \\
\hline 5 & 80 & 44.4 & 43.1 & 1.1 & 0.2 & 97 & 3879 & $15.39 \times 10^{-2}$ \\
\hline 6 & 90 & 81.4 & 72.4 & 8.0 & 1.0 & 89 & 6516 & $25.86 \times 10^{-2}$ \\
\hline 7 & 100 & 95.2 & 83.1 & 11.0 & 1.1 & 87 & 7479 & $29.68 \times 10^{-2}$ \\
\hline
\end{tabular}

aConversion or yield in mol \%; ${ }^{b S}$ (selectivity) in percent toward PMPs; 'TON (turnover number) $=\left[\%\right.$ PMPs $\times\left(\right.$ Oct/Ru)]/100; ${ }^{d}$ TOF (turnover frequency) $=$ TON/time in s. 
and then to $100{ }^{\circ} \mathrm{C}(87 \%)$. An overall assessment of the results show that at $80^{\circ} \mathrm{C}$ the catalyst showed a high selectivity for PMPs with a negligible amount of SMPs and IPs. Although the activity of the precatalyst increased a great deal at 90 and $100{ }^{\circ} \mathrm{C}$, the selectivity for PMPs decreased as a result of the high amount of SMPs and IPs formation. The TOF increased significantly as a result of increasing the temperature. The highest TOF increase was observed upon increasing the temperature from 80 to $90{ }^{\circ} \mathrm{C}$. Generally, precatalyst 7 showed very good activity, selectivity and stability at high temperatures.

The results of the metathesis of 1-octene at temperatures $40-100{ }^{\circ} \mathrm{C}$ are presented in Figure 6 and Table 3 for precatalyst 8. A similar overall trend for $\mathbf{8}$ is observed, i.e., very low reaction rates at temperatures below $60{ }^{\circ} \mathrm{C}$ with a rapid increase in reaction rates above $70{ }^{\circ} \mathrm{C}$ resulting in 1-octene conversions above ca. $70 \%$ after $540 \mathrm{~min}$. Although the formation of PMPs equilibrated quickly at ca. $70 \%$ after ca. $150 \mathrm{~min}$ at $100{ }^{\circ} \mathrm{C}$ and at ca. $65 \%$ only after ca. $400 \mathrm{~min}$ for $90{ }^{\circ} \mathrm{C}$ it did not equilibrate at $80{ }^{\circ} \mathrm{C}$ even after $540 \mathrm{~min}$.

The formation of SMPs is very low (below 4\%) for 8 in the temperature range $40-80{ }^{\circ} \mathrm{C}$ after $540 \mathrm{~min}$, while it is relatively high at 14 and $21 \%$ at 90 and $100{ }^{\circ} \mathrm{C}$, respectively. In the same period the formation of IPs remained below 3\% even at the high temperatures. At $100{ }^{\circ} \mathrm{C}$ and $540 \mathrm{~min}$, a larger amount of SMPs is formed for precatalyst 8 than that of 7.

Table 3 summarises the overall catalytic performance of precatalyst 8 at 420 min. The PMPs and SMPs formation, TON and TOF all show a direct relationship with temperature. Precatalysts $\mathbf{7}$ and $\mathbf{8}$ share similarities in having the same temperature range for the highest PMPs formation, i.e., 70 to $80{ }^{\circ} \mathrm{C}$ at $420 \mathrm{~min}$. The biggest difference, however, is observed for 8 (37\%). Relatively higher SMPs are formed for 8 (11\%, 19\%) than that of $7(8 \%, 11 \%)$ at 90 and $100{ }^{\circ} \mathrm{C}$, respectively. The relatively low PMPs formation of $\mathbf{8}$ compared to that of $\mathbf{7}$ is due to the relatively high SMPs and IPs formations with precatalyst 8. The IPs formation in $\mathbf{8}$ follows a similar pattern to that of $\mathbf{7}$, i.e., it showed an increase upon increasing the temperature from 40 to $50{ }^{\circ} \mathrm{C}$, followed by a decrease from 50 to $60{ }^{\circ} \mathrm{C}$ and then an increase from 60 to $100{ }^{\circ} \mathrm{C}$. The selectivity in 8 increased upon increasing the temperature from 40 to $70{ }^{\circ} \mathrm{C}$, and then showed a decrease from 70 to $100{ }^{\circ} \mathrm{C}$.

A maximum selectivity for 8 is observed at $70{ }^{\circ} \mathrm{C}(94 \%)$ (see Table 3, entry 4) and for that of 7 at $80^{\circ} \mathrm{C}(97 \%)$ (see Table 2, entry 5). Generally, precatalyst 7 showed a better selectivity

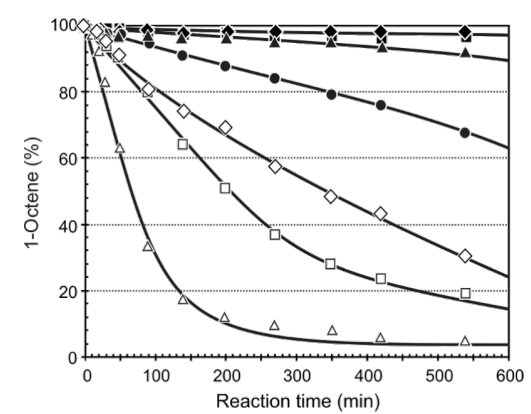

(a)

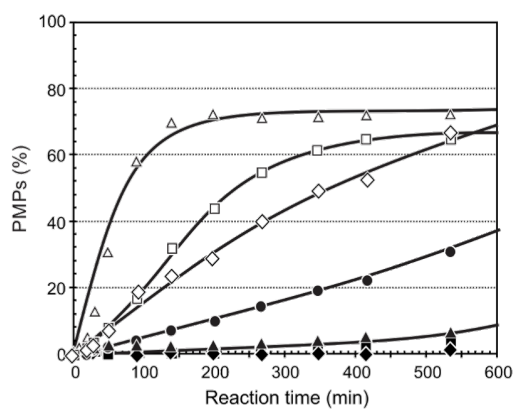

(b)

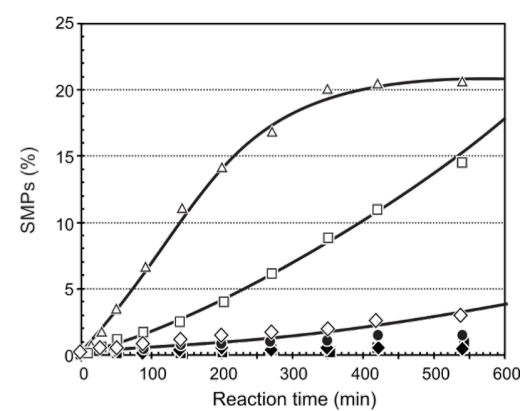

(c)

Figure 6: The influence of the reaction temperature on the (a) conversion of 1-octene, (b) formation of PMPs and (c) formation of SMPs using precatalyst $8(\mathrm{Ru} / 1$-octene $=1: 9000) . \bullet 40^{\circ} \mathrm{C}, \square 50^{\circ} \mathrm{C}, \Delta 60^{\circ} \mathrm{C}, \bullet 70^{\circ} \mathrm{C}, \diamond 80^{\circ} \mathrm{C}, \square 90^{\circ} \mathrm{C}, \Delta 100{ }^{\circ} \mathrm{C}$.

Table 3: Summary of catalytic performance of precatalyst 8 at different temperatures (Ru/1-octene molar ratio 1:9 000, 420 min).

\begin{tabular}{|c|c|c|c|c|c|c|c|c|}
\hline Entry & Temp. $\left[{ }^{\circ} \mathrm{C}\right]$ & Conv. ${ }^{a}$ & $\mathrm{PMPs}^{\mathrm{a}}$ & SMPs $^{a}$ & $\mathrm{IPs}^{\mathrm{a}}$ & $\mathrm{s}^{b}$ & $\mathrm{TON}^{\mathrm{C}}$ & TOF $^{d}$ \\
\hline 1 & 40 & 1.5 & 0.8 & 0.3 & 0.4 & 56 & 72 & $0.28 \times 10^{-2}$ \\
\hline 2 & 50 & 2.9 & 1.4 & 0.6 & 0.9 & 49 & 126 & $0.50 \times 10^{-2}$ \\
\hline 3 & 60 & 5.3 & 4.5 & 0.7 & 0.1 & 85 & 405 & $1.61 \times 10^{-2}$ \\
\hline 4 & 70 & 24.0 & 22.7 & 1.1 & 0.2 & 94 & 2043 & $8.11 \times 10^{-2}$ \\
\hline 5 & 80 & 65.4 & 60.5 & 4.1 & 0.8 & 92 & 5445 & $21.61 \times 10^{-2}$ \\
\hline 6 & 90 & 77.3 & 65.0 & 11.0 & 1.3 & 84 & 5850 & $23.21 \times 10^{-2}$ \\
\hline 7 & 100 & 93.8 & 73.0 & 19.0 & 1.8 & 78 & 6570 & $26.07 \times 10^{-2}$ \\
\hline
\end{tabular}

aConversion or yield in mol \%; ${ }^{b S}$ (selectivity) in percent toward PMPs; 'TON (turnover number) $=\left[\%\right.$ PMPs $\times\left(\right.$ Oct/Ru)]/100; ${ }^{d}$ TOF (turnover frequency) $=$ TON/time in s. 
compared to that of 8 at $420 \mathrm{~min}$. Although the TOF of $\mathbf{8}$ is in direct relation with temperature, it follows the following order upon comparing with 7;8>7 at 40 and $50{ }^{\circ} \mathrm{C}$ (see Table 2 and Table 3, entries 1-7), at $60{ }^{\circ} \mathrm{C} \mathbf{7}>\mathbf{8}$ (see Table 2 and Table 3 , entry 3), at 70 and $80{ }^{\circ} \mathrm{C} 8>7$ (see Table 2 and Table 3, entries 4 and 5) and $7>8$ at 90 and $100{ }^{\circ} \mathrm{C}$ (see Table 2 and Table 3, entries 6 and 7).

Summarising the comparisons of precatalysts $\mathbf{7}$ and $\mathbf{8}$, it is noted that precatalyst 7 showed better activity, selectivity and stability in the $60-100{ }^{\circ} \mathrm{C}$ temperature range, except for $80{ }^{\circ} \mathrm{C}$, at $420 \mathrm{~min}$. It also showed higher TOF at 60,90 and $100{ }^{\circ} \mathrm{C}$ at 420 min. According to a DFT study by Getty et al. [19] the more positively charged the $\mathrm{Ru}$, the slower the initiation rate of the catalyst. The calculated Mulliken atomic charge of Ru in 7 (0.934) is less positive than in $8(0.976)$.

The results of the metathesis of 1-octene at temperatures of 60 to $110^{\circ} \mathrm{C}$ are presented in Figure 7 and Figure 8 for precatalysts 6 and 9, respectively. Because of their low activity and high stability, the metathesis reactions were done between 60 and $110^{\circ} \mathrm{C}$. Metathesis of 1 -octene by the 3-Me-substituted precatalyst 6 showed an increase in the activity of the precatalyst upon increasing the temperature from 60 to $110^{\circ} \mathrm{C}$. A large increase in the rate of the metathesis reaction is observed upon increasing the temperature from 80 to $90{ }^{\circ} \mathrm{C}$. Although the activity of the precatalyst has shown an increase upon increasing the temperature from 60 to $110^{\circ} \mathrm{C}$, a very high (ca. $45 \%$ ) increase in the PMPs formation is observed upon increasing the temperature from 80 to $90{ }^{\circ} \mathrm{C}$ at $540 \mathrm{~min}$. The PMPs formation did not equilibrate at $90{ }^{\circ} \mathrm{C}$ and this shows the stability of precatalyst 6 at high temperatures. The PMPs formation, however, equilibrated from ca. $270 \mathrm{~min}$ at $100{ }^{\circ} \mathrm{C}$ and ca. $140 \mathrm{~min}$ at $110^{\circ} \mathrm{C}$. At $80^{\circ} \mathrm{C}$, the activity of precatalyst 6 (ca. $25 \%$ ) is very low compared to precatalysts 7 (ca. 50\%) and 8 (ca. 70\%) during the course of PMPs formation, at $540 \mathrm{~min}$. Generally, in the first 100 to 300 minutes, the rate of formation of PMPs increases dramatically and slows down afterwards in the temperature range of 90 to $110^{\circ} \mathrm{C}$. A similar trend is observed during the course of SMPs formation. Significant amounts (16-36\%) of SMPs are formed by 6 for temperatures 90 to $110{ }^{\circ} \mathrm{C}$, while negligible amounts $(1.3-3.6 \%)$ of SMPs are formed from 60 to $80{ }^{\circ} \mathrm{C}$. Large amounts of SMPs (ca. 36\%) and IPs (5\%) were formed by 6 at $540 \mathrm{~min}$ at $100{ }^{\circ} \mathrm{C}$. A comparison of precata-

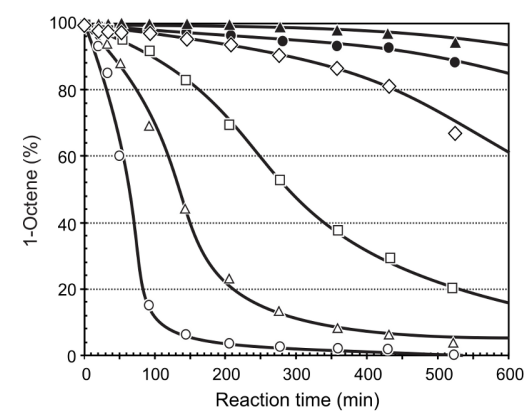

(a)

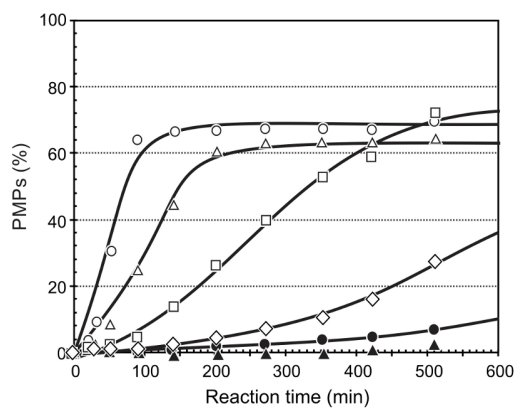

(b)

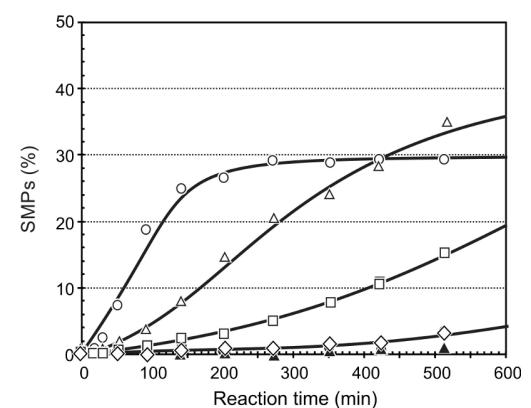

(c)

Figure 7: The influence of the reaction temperature on the (a) conversion of 1-octene, (b) formation of PMPs and (c) formation of SMPs using precatalyst $6(\mathrm{Ru} / 1$-octene $=1: 9000)$. $\left[\Delta 60^{\circ} \mathrm{C}, \bullet 70^{\circ} \mathrm{C}, \diamond 80^{\circ} \mathrm{C}, \square 90^{\circ} \mathrm{C}, \Delta 100{ }^{\circ} \mathrm{C}, \circ 110^{\circ} \mathrm{C}\right]$.

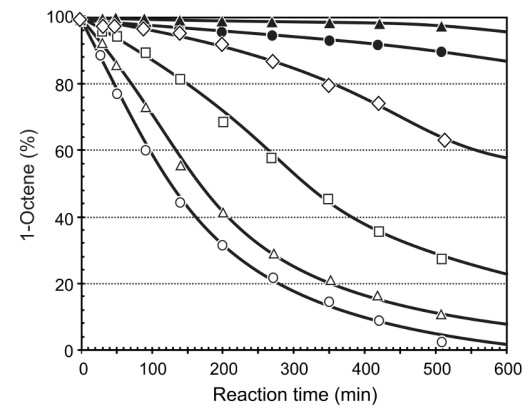

(a)

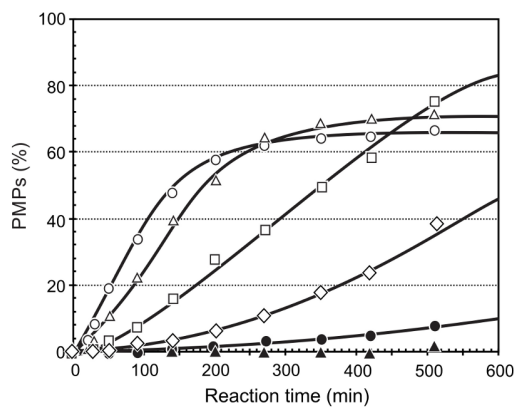

(b)

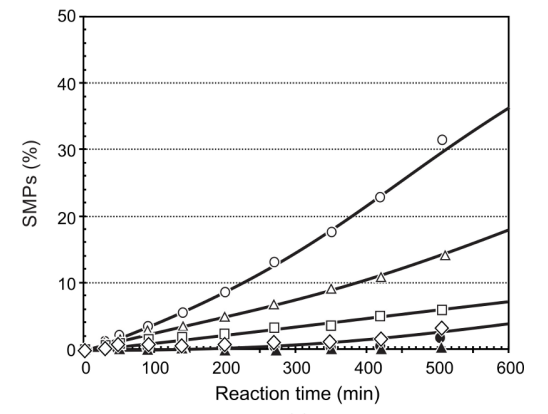

(c)

Figure 8: The influence of the reaction temperature on the (a) conversion of 1-octene, (b) formation of PMPs and (c) formation of SMPs using precatalyst 9 (Ru/1-octene $=1: 9000)$. $\left[\Delta 60^{\circ} \mathrm{C}, \bullet 70^{\circ} \mathrm{C}, \diamond 80^{\circ} \mathrm{C}, \square 90^{\circ} \mathrm{C}, \Delta 100{ }^{\circ} \mathrm{C}, \circ 110^{\circ} \mathrm{C}\right]$. 
lysts 6,7 and $\mathbf{8}$ with regard to SMPs and IPs formation at $100{ }^{\circ} \mathrm{C}$ and $540 \mathrm{~min}$ shows a decreasing order of $6>8>7$. Generally, a relatively large amount of IPs is formed by precatalyst 6. Although the rate of PMPs formation is slow at $80{ }^{\circ} \mathrm{C}$, high selectivity and stability are attained at this temperature for precatalyst 6 , similar to precatalysts 7 and 8 . The highest difference in the PMPs formation (ca. 45\%) is observed between 80 and $90^{\circ} \mathrm{C}$. Although the SMPs formation has shown a direct relationship with temperature, the formation of high SMPs (16-36\%) from 90 to $110^{\circ} \mathrm{C}$ limited the PMPs formation to only a maximum of ca. $68 \%$ at $540 \mathrm{~min}$. The contribution of the IPs formation in limiting the formation of PMPs is not negligible as a result of the relatively high (ca. 3.5\%) IPs formation. The SMPs formation increased approximately six-fold upon increasing the temperature from 80 to $90^{\circ} \mathrm{C}$, which was then followed by approximately a two-fold increase upon increasing the temperature from 90 to $100{ }^{\circ} \mathrm{C}$.

Table 4 presents the overall catalytic performance of precatalyst 6 at $420 \mathrm{~min}$. At $420 \mathrm{~min}, 1$-octene conversion is $98.0 \%$ $\left(110^{\circ} \mathrm{C}\right), 93.0 \%\left(100{ }^{\circ} \mathrm{C}\right), 70.5 \%\left(90^{\circ} \mathrm{C}\right), 19.4 \%\left(80{ }^{\circ} \mathrm{C}\right), 6.8 \%$ $\left(70{ }^{\circ} \mathrm{C}\right)$ and $2.5 \%\left(60^{\circ} \mathrm{C}\right)$. This shows the dramatic increase of the catalytic activity upon increasing the temperature. An investigation of the PMPs formation reveals a huge $66 \%$ increase for the PMPs formation upon increasing the reaction temperature from 60 to $110{ }^{\circ} \mathrm{C}$. The IPs formation, on the other hand, increased two-fold upon increasing the temperature from 60 to $70{ }^{\circ} \mathrm{C}, 80$ to $90{ }^{\circ} \mathrm{C}$ and 90 to $100{ }^{\circ} \mathrm{C}$.

The selectivity toward PMPs (67.2\%) and the SMPs (28.8\%) are relatively high at $110^{\circ} \mathrm{C}$. The TOF is also directly related to the reaction temperature. The TOF of precatalyst 6 are generally lower than for precatalysts 7 and $\mathbf{8}$. This, therefore, shows the relatively high stability of precatalyst 6 compared to those of 7 and $\mathbf{8}$. As a result of having a more positive $\mathrm{Ru}$ charge, precatalyst 6 showed a low initiation rate. This is also in agreement with the DFT study of Getty et al. [19], i.e., precatalyst 6 (0.988) has more positive Mulliken's atomic charge on Ru than both $7(0.934)$ and $8(0.976)$. Its high activity at $110^{\circ} \mathrm{C}$ with $69 \%$ selectivity is, however, remarkable for linear alkene metathesis catalysed by ruthenium alkylidene precatalysts.

The 3-OMe-substituted precatalyst 9 showed a negligible activity for the metathesis of 1 -octene at $60{ }^{\circ} \mathrm{C}$ (Figure 8), similar to the 3-Me-substituted precatalyst 6 . The overall activity of the precatalyst, however, showed a significant increase upon increasing the temperature from 60 to $110^{\circ} \mathrm{C}$. In a similar way to that of 6 , the largest increase in the activity of the precatalyst is observed upon increasing the temperature from 80 to $90{ }^{\circ} \mathrm{C}$ (ca. 38\%) at $420 \mathrm{~min}$. The activity of the catalyst showed a small difference between 100 and $110^{\circ} \mathrm{C}$, on the overall metathesis reaction.

During the course of PMPs formation, high catalytic activity for 9 is observed within $200 \mathrm{~min}$ at temperatures above $90{ }^{\circ} \mathrm{C}$ (ca. $60 \%$ ), while the activity of the precatalyst showed a dramatic increase from 70 to $90^{\circ} \mathrm{C}$ after ca. $500 \mathrm{~min}$, similar to that of 6 (see Figure 7b). For both 6 and 9 the highest PMPs $(>60 \%)$ is observed from 90 to $110^{\circ} \mathrm{C}$ after $420 \mathrm{~min}$. The rate of formation of SMPs is very high for 9 at $110{ }^{\circ} \mathrm{C}$ within $420 \mathrm{~min}$. This is the reason for the decrease in the formation of PMPs from $71 \%$ at $100{ }^{\circ} \mathrm{C}$ to $64.2 \%$ at $110^{\circ} \mathrm{C}$.

Table 5 presents the overall catalytic performance of precatalyst 9 at 420 min. Firstly, PMPs formation increased from 0.5 to $71 \%$ when increasing the temperature from 60 to $100{ }^{\circ} \mathrm{C}$; however, from 100 to $110^{\circ} \mathrm{C}$ the PMPs yield decreased from 71 to $64.2 \%$. The reason for this is the formation of a very large amount of SMPs $(23.2 \%)$ and IPs $(2.6 \%)$, which is, more than twice the amount at $100{ }^{\circ} \mathrm{C}$. Similarly, the selectivity and TOF showed a decrease when going from 100 to $110^{\circ} \mathrm{C}$.

The selectivity showed a dramatic $(50 \%)$ increase upon increasing the temperature from $60(43 \%)$ to $80{ }^{\circ} \mathrm{C}(93 \%)$ and then begins to decrease to $91 \%$ (at $90{ }^{\circ} \mathrm{C}$ ), $85 \%$ (at $100{ }^{\circ} \mathrm{C}$ ) and finally to $71 \%$ (at $110^{\circ} \mathrm{C}$ ). Although the catalyst showed signif-

\begin{tabular}{|c|c|c|c|c|c|c|c|c|}
\hline Entry & Temp. $\left[{ }^{\circ} \mathrm{C}\right]$ & Conv. $^{a}$ & $\mathrm{PMPs}^{\mathrm{a}}$ & $\mathrm{SMPs}^{\mathrm{a}}$ & $\mathrm{IPs}^{\mathrm{a}}$ & $S^{b}$ & $\mathrm{TON}^{\mathrm{C}}$ & TOF $^{d}$ \\
\hline 1 & 60 & 2.5 & 1.0 & 0.9 & 0.6 & 41 & 93 & $0.36 \times 10^{-2}$ \\
\hline 2 & 70 & 6.8 & 4.5 & 1.0 & 1.3 & 66 & 406 & $1.61 \times 10^{-2}$ \\
\hline 3 & 80 & 19.4 & 16.4 & 2.3 & 0.7 & 85 & 1479 & $5.86 \times 10^{-2}$ \\
\hline 4 & 90 & 70.5 & 59.0 & 10.3 & 1.2 & 83 & 5310 & $21.07 \times 10^{-2}$ \\
\hline 5 & 100 & 93.0 & 61.3 & 28.5 & 3.9 & 66 & 5514 & $21.88 \times 10^{-2}$ \\
\hline 6 & 110 & 98.0 & 67.2 & 28.8 & 2.1 & 69 & 6051 & $24.01 \times 10^{-2}$ \\
\hline
\end{tabular}

${ }^{a}$ Conversion or yield in mol \%; ${ }^{b S}$ (selectivity) in percent toward PMPs; ${ }^{\mathrm{C} T O N}$ (turnover number) $=[\% \mathrm{PMPs} \times(\mathrm{Oct} / \mathrm{Ru})] / 100 ;{ }^{\mathrm{d}} \mathrm{TOF}$ (turnover frequency) $=$ TON/time in s. 


\begin{tabular}{|c|c|c|c|c|c|c|c|c|}
\hline Entry & Temp. $\left[{ }^{\circ} \mathrm{C}\right]$ & Conv. $^{a}$ & $\mathrm{PMPs}^{\mathrm{a}}$ & $\mathrm{SMPs}^{a}$ & $\mathrm{IPs}^{\mathrm{a}}$ & $S^{b}$ & $\mathrm{TON}^{\mathrm{C}}$ & TOF $^{d}$ \\
\hline 1 & 60 & 1.1 & 0.5 & 0.3 & 0.3 & 43 & 45 & $0.18 \times 10^{-2}$ \\
\hline 2 & 70 & 7.3 & 5.3 & 1.1 & 0.9 & 73 & 477 & $1.89 \times 10^{-2}$ \\
\hline 3 & 80 & 25.7 & 24.0 & 1.4 & 0.3 & 93 & 2160 & $8.57 \times 10^{-2}$ \\
\hline 4 & 90 & 64.0 & 58.3 & 5.1 & 0.6 & 91 & 5247 & $20.82 \times 10^{-2}$ \\
\hline 5 & 100 & 83.3 & 71.0 & 11.1 & 1.2 & 85 & 6390 & $25.36 \times 10^{-2}$ \\
\hline 6 & 110 & 90.0 & 64.2 & 23.2 & 2.6 & 71 & 5778 & $22.93 \times 10^{-2}$ \\
\hline
\end{tabular}

${ }^{\mathrm{a} C}$ Conversion or yield in mol \%; ${ }^{\mathrm{b} S}$ (selectivity) in percent toward PMPs; ${ }^{\mathrm{T}} \mathrm{TON}$ (turnover number) $=[\% \mathrm{PMPs} \times(\mathrm{Oct} / \mathrm{Ru})] / 100$; ${ }^{\mathrm{d}} \mathrm{TOF}($ turnover frequency) $=$ TON/time in s.

icant stability and very good $(71 \%)$ selectivity at $110^{\circ} \mathrm{C}$, it is advisable not to go beyond $100{ }^{\circ} \mathrm{C}$, as the formation of SMPs and IPs doubled that will affect the overall PMPs yield. It is also worthwhile to note the decrease in the turnover frequency at $110{ }^{\circ} \mathrm{C}$.

Similar to the Me-substituted precatalysts 6 (85\%) (see Table 4, entry 3), 7 (97\%) (see Table 2, entry 5) and 8 (92\%) (see Table 3, entry 5), precatalyst 9 showed high selectivity (93\%) towards PMPs and good stability at $80{ }^{\circ} \mathrm{C}$ after $420 \mathrm{~min}$. It is also observed from the results that precatalyst 9 showed relatively high selectivity (91\%) for PMPs and good activity, higher than its methyl counterparts 6 (83\%) (see Table 4, entry 4), 7 (84\%) (see Table 2, entry 6) and 8 (89\%) (see Table 3, entry 6), at $90{ }^{\circ} \mathrm{C}$ after $420 \mathrm{~min}$.

A general comparison of the overall performance of the precatalysts, in terms of PMPs, SMPs, IPs, selectivity, TON and TOF, exhibits the decreasing order of $7>\mathbf{9}>\mathbf{8}>\mathbf{6}$ at 60,90 and $100{ }^{\circ} \mathrm{C}$. The order, however, changes at $80{ }^{\circ} \mathrm{C}$ to $8>7>9>6$ and at $70{ }^{\circ} \mathrm{C}$ to $7 \cong \mathbf{8}>\mathbf{9}>\mathbf{6}$. In all cases, the small amounts of SMPs and IPs are positive for the application of these systems at higher temperatures. Overall precatalyst 7 performed the best at all temperatures (except at $80^{\circ} \mathrm{C}$ ). In an attempt to understand the significance of these results, DFT calculations were performed on the precatalysts.

Precatalyst 6 showed the lowest activity of all precatalysts in the specified temperature ranges. It is also worthwhile to note that increasing the reaction temperature showed a significant increase in the activity of $\mathbf{6}$. Precatalyst $\mathbf{9}$, on the other hand, showed better performance at high temperatures $\left(\geq 70{ }^{\circ} \mathrm{C}\right) \mathrm{com}$ pared to 6 . This may be explained by the longer $\mathrm{Ru}-\mathrm{N}$ bond $(2.181 \AA)$ in the geometry-optimised structure (Figure 9) of precatalyst 9 compared to that of the $\mathrm{Ru}-\mathrm{N}$ bond (2.166 $\AA$ ) of 6 . A longer bond suggests a weaker $\mathrm{Ru}-\mathrm{N}$ chelation thus a more active hemilabile complex. The difference in the $\mathrm{Ru}-\mathrm{N}$ bond length may be attributed to the electron-withdrawing inductive effect of the OMe group making the $\mathrm{Ru}-\mathrm{N}$ chelation weaker. Furthermore, a type of orbital interaction between the oxygen of the 3-OMe group and the two $\alpha$-phenyl rings, i.e., an oxygen lone pair-aromatic $\pi$ interaction illustrated in Figure 10, may add to the inductive effect. The longer $\mathrm{Ru}-\mathrm{O}$ bond (2.031 $\AA$ ), shorter $\mathrm{C}_{\alpha}-\mathrm{O}$ bond $(1.420 \AA)$ and $\mathrm{C}_{\alpha}-\mathrm{C}_{2}$ bond (1.541 $\AA$ ) observed in precatalyst 9 when compared to the corresponding bonds in 6, i.e., $2.028,1.425$ and $1.544 \AA$, respectively, supports

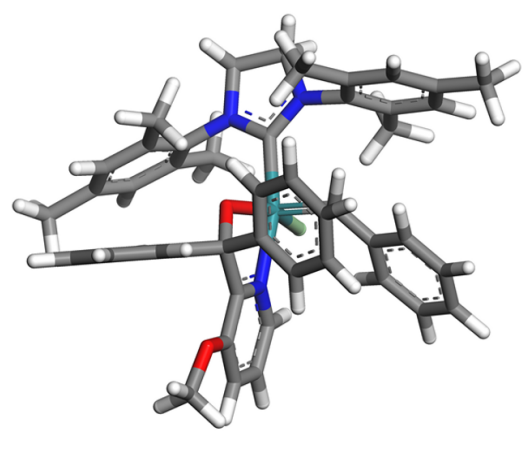

9

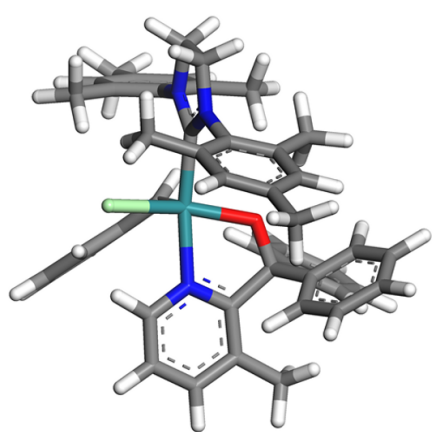

6

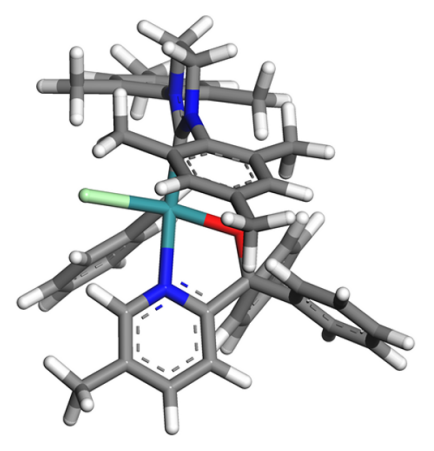

8

Figure 9: Geometry-optimised structures of precatalyst 9, 6 and 8. 
such a premise. It may also be a plausible explanation for the envelope geometry of the five-membered ruthenacycle. In addition, the relatively low ruthenium metal positive charge on 9 would cause it to have a high initiation rate constant [19].

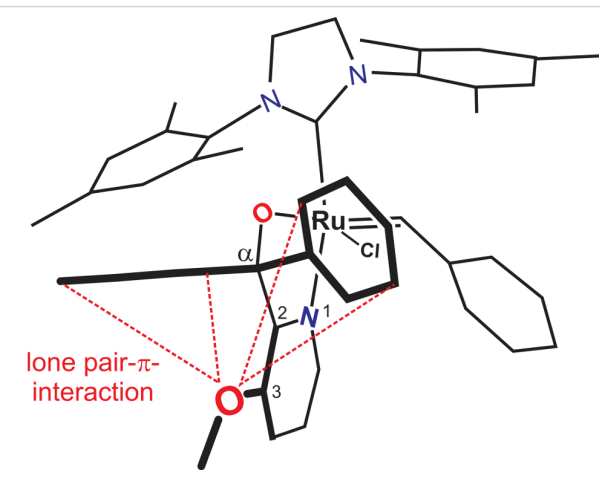

Figure 10: An illustration of the envisaged methoxy oxygen lone pairaromatic $\pi$-electron interaction.

On the other hand, the 3-Me group in $\mathbf{6}$ will strengthen the $\mathrm{Ru}-\mathrm{N}$ chelation via inductive electron-donation and steric repulsion between the methyl group and the two phenyl rings. As a result of the steric interaction 6 has a planar five-membered ruthenacycle geometry (Figure 9). In the absence of substituents on the pyridinyl moiety it is expected that the resulting precatalyst will be more active at lower temperatures. This is indeed the case when $\mathbf{5 d}$ is used as catalyst.

As we have discussed earlier, the 4-Me-substituted precatalyst 7 has shown better catalytic performance in all temperatures under investigation except at $80^{\circ} \mathrm{C}$. The reason for this is that the Me group is, relatively speaking, further removed from the pyridine nitrogen so that the inductive electron-donation by the methyl group cannot significantly influence the electron density on the pyridine nitrogen. There is also no steric effect that would interfere with the $\mathrm{Ru}-\mathrm{N}$ bond strength. The strengthening effect on the $\mathrm{Ru}-\mathrm{N}$ chelation would, therefore, possibly be low compared to the other precatalysts.

If this is a plausible explanation for the relatively better performance of the 4-Me-substituted precatalyst 7, one might ask what about the difference between the 3-Me-, 6, and 5-Mesubstituted, 8 , precatalysts that are at the same distance from the pyridine nitrogen? In the optimised structure of $\mathbf{6}$, the Me group is in a crowded environment due to its proximity to the two $\alpha$-phenyl groups, which upon opening the $\mathrm{Ru}-\mathrm{N}$ chelation, would even become more sterically crowded. This results in a planar geometry of the five-membered ruthenacycle while 8 exhibits an envelope geometry. The $\mathrm{Ru}-\mathrm{N}(2.179 \AA)$ bond length in 8 is longer and the $\mathrm{C}_{\alpha}-\mathrm{O}(1.417 \AA)$ and $\mathrm{C}_{\alpha}-\mathrm{C}_{2}(1.532 \AA)$ bonds are shorter than the corresponding bonds in 6 .
In order to overcome the combined effect of the resistance that resulted from the steric crowdedness and the inductive electrondonation by the 3-Me group and open the strong $\mathrm{Ru}-\mathrm{N}$ chelation, it needs relatively high energy. In $\mathbf{8}$ the methyl group is in exactly the opposite orientation to the two $\alpha$-phenyl groups. Therefore, the steric crowdedness that is observed in $\mathbf{6}$ that will lead to steric resistance to open the $\mathrm{Ru}-\mathrm{N}$ chelation does not exist. Thus $\mathbf{8}$ is more susceptible to hemilability than $\mathbf{6}$ and exhibits higher activity. Therefore, for 4-Me- and 5-Me-subtstituted precatalysts, only the inductive electron-donation effect of the methyl group is the reason for the increased stability. In the 3-Me- and 3-OMe-substituted precatalysts, however, the steric effect and orbital interactions work towards the stability of the precatalyst in addition to inductive effects.

\section{Stability of precatalysts}

In previous studies $[11,12,14]$ we investigated the stability of pyridinyl-alcoholate Grubbs-type precatalysts as seen in the improved catalytic lifetimes of these complexes. Plots of $\ln ([$ starting material] $)$ versus time, proposed by Grubbs and co-workers [20], were used as a measure of the stability of the precatalyst, i.e., a linear plot indicates a reaction with pseudofirst order rate kinetics, while a curved plot points towards catalyst decomposition. We used the conversion of 1-octene at a $\mathrm{Ru} / 1$-octene molar ratio of $1: 9000$ and a reaction temperature of $80{ }^{\circ} \mathrm{C}$ to compare the stability of $\mathbf{5 d}$ with that of $\mathbf{5 i}, \mathbf{5 j}$ and $\mathbf{5 k}$ [14]. In Figure 11 the literature data (\% 1-octene conversion and $\ln (\% 1$-octene $))$ of $\mathbf{5 d}$ is compared with that of precatalysts $6-9$ at a $\mathrm{Ru} / 1$-octene molar ratio of 1:9000 and a reaction temperature of $80{ }^{\circ} \mathrm{C}$ over $540 \mathrm{~min}$.

The overall activity order of the catalysts follows the order $\mathbf{5 d}>\mathbf{8}>\mathbf{7}>\mathbf{9}>\mathbf{6}$ up to ca. $540 \mathrm{~min}$. The order $\mathbf{8}>\mathbf{5 d} \cong \mathbf{7}>$ $9>6$ is observed for both the overall metathesis and the PMPs formation. All the precatalysts exhibits first-order kinetics over the first ca 540 min when the $\ln (\%$ 1-octene) plots (Figure 11b) are considered. The substituted precatalysts show better stability than $\mathbf{5 d}$, thus longer lifetimes, with $\mathbf{6}$ and $\mathbf{9}$ the slowest and $\mathbf{8}$ close to but slower than $\mathbf{5 d}$.

It is interesting to note that the stability of $\mathbf{5 j}$ and $\mathbf{5} \mathbf{k}$ correlates very well with that of $\mathbf{7}$, while $\mathbf{5 i}$ is more stable than 7 but less than 9 (comparison of current results with results in [14]). This clearly indicates that a substituent on one of the $\alpha$-phenyl groups or the pyridinyl moiety has a stabilising effect on the corresponding precatalyst with a substituent on the 3-position (6 and 9) of the pyridinyl rendering the precatalyst the most stable. The latter two is also active at higher temperatures.

Table 6 presents the overall catalytic performance of precatalysts 5d, and 6-9 at a $\mathrm{Ru} / 1$-octene molar ratio of 1:9000, $80^{\circ} \mathrm{C}$ 


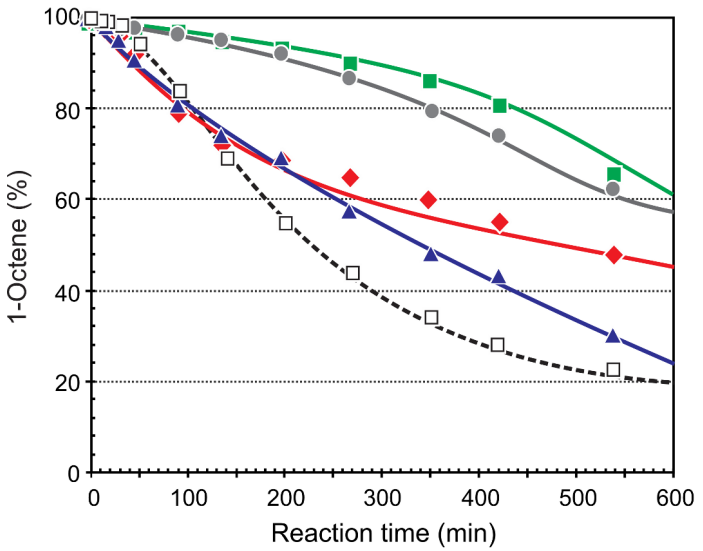

(a)

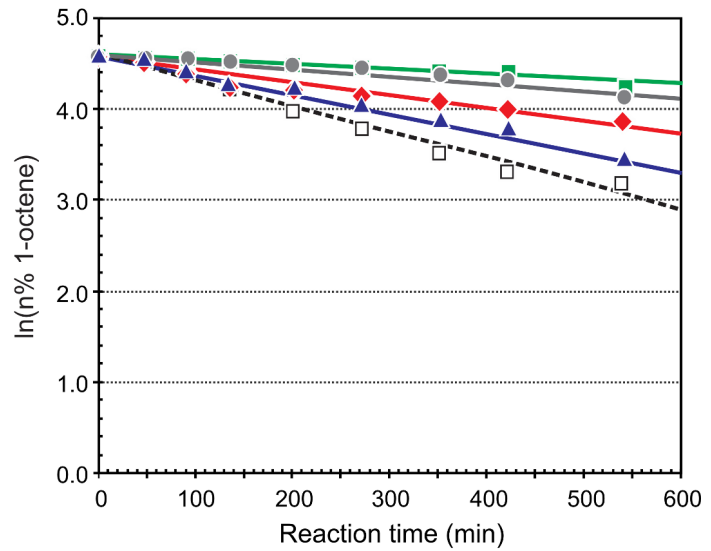

(b)

Figure 11: Influence of precatalysts $6-9$ and $\mathbf{5 d}$ on the (a) conversion of 1 -octene and $(\mathrm{b}) \ln ([n \% 1$-octene $])$ versus time plots $(\mathrm{Ru} / 1-\mathrm{octene}=1: 9000$; $\left.80^{\circ} \mathrm{C}\right) .[\bullet 6, \bullet \mathbf{7}, \Delta \mathbf{8}, \bullet \mathbf{9}, \square \mathbf{5 d}]$

Table 6: Summary of catalytic performances of different precatalyst (Ru/1-octene molar ratio $\left.1: 9000,80^{\circ} \mathrm{C}, 420 \mathrm{~min}\right)$.

\begin{tabular}{|c|c|c|c|c|c|c|c|c|}
\hline Entry & Precat. & Conv. ${ }^{a}$ & $\mathrm{PMPs}^{\mathrm{a}}$ & $\mathrm{SMPs}^{\mathrm{a}}$ & $\mathrm{IPs}^{\mathrm{a}}$ & $\mathrm{S}^{\mathrm{b}}$ & $\mathrm{TON}^{\mathrm{C}}$ & TOF $^{d}$ \\
\hline 1 & $5 d^{e}$ & 71.2 & 68.0 & 3.0 & 0.3 & 96 & 6120 & $24.29 \times 10^{-2}$ \\
\hline 2 & 8 & 65.4 & 60.5 & 4.1 & 0.8 & 92 & 5445 & $21.61 \times 10^{-2}$ \\
\hline 3 & 7 & 44.4 & 43.1 & 1.1 & 0.2 & 97 & 3879 & $15.39 \times 10^{-2}$ \\
\hline 4 & 9 & 25.7 & 24.0 & 1.4 & 0.3 & 93 & 2160 & $8.57 \times 10^{-2}$ \\
\hline 5 & 6 & 19.4 & 16.4 & 2.3 & 0.7 & 85 & 1476 & $5.86 \times 10^{-2}$ \\
\hline
\end{tabular}

${ }^{a}$ Conversion or yield in mol \%; bS (selectivity) in percent toward PMPs; ${ }^{\mathrm{C} T O N}$ (turnover number) $=[\% \mathrm{PMPs} \times(\mathrm{Oct} / \mathrm{Ru})] / 100$; ${ }^{\mathrm{d}} \mathrm{TOF}$ (turnover frequency) $=$ TON/time in s; ${ }^{\text {e }}$ See reference [14].

and $420 \mathrm{~min}$. According to these results precatalyst 5d shows the highest PMPs, TON and TOF. Although it has relatively high SMPs compared to most of the precatalysts, its overall performace prevails over the other precatalysts. The second best performance was observed for $\mathbf{8}$, as it resulted in relatively high PMPs, TON and TOF compared to the rest of the precatalysts, although its SMPs ranks as first. The rest of the precatalysts can be ranked in a decreasing order of activity of $7>9>6$. It is clear from the data in Table 6 that the unsubstituted precatalyst 5d is more active compared to the substituted precatalysts at $420 \mathrm{~min}$. This will only be due to the substituent effect on the activity of the precatalyst.

\section{Effect of catalyst concentration}

Earlier studies indicated that $80{ }^{\circ} \mathrm{C}$ is the optimum temperature for $\mathbf{5 d}[10,11]$. It was therefor decided to investigate the effect of the concentration of the precatalyst on the metathesis of 1 -octene at $80{ }^{\circ} \mathrm{C}$. Precatalyst 8 was chosen for this investigation at $\mathrm{Ru} / 1$-octene molar ratios of 1:6000, 1:9000, 1:10000 and $1: 15000$.

Table 7 presents the overall catalytic performance of precatalyst 8 at different $\mathrm{Ru} / 1$-octene molar ratios, $80^{\circ} \mathrm{C}$ and $420 \mathrm{~min}$. With a decrease in precatalyst concentration a direct relationship was observed with the conversion of 1-octene and PMPs,

Table 7: Summary of the catalytic performance of precatalyst 8 present in different concentrations $\left(80^{\circ} \mathrm{C}, 420 \mathrm{~min}\right)$.
\begin{tabular}{llllllllll} 
Entry & $\mathrm{C}_{8}: \mathrm{Ru}$ & Conv. $^{\mathrm{a}}$ & PMPs $^{\mathrm{a}}$ & $\mathrm{SMPs}^{\mathrm{a}}$ & IPs $^{\mathrm{a}}$ & $\mathrm{S}^{\mathrm{b}}$ & TON $^{\mathrm{C}}$ & TOF $^{\mathrm{d}}$ \\
\hline 1 & 6000 & 76.9 & 70.7 & 5.9 & 0.4 & 92 & 4240 & $16.83 \times 10^{-2}$ \\
2 & 9000 & 65.4 & 60.5 & 4.1 & 0.8 & 92 & 5445 & $21.61 \times 10^{-2}$ \\
3 & 10000 & 60.2 & 55.4 & 4.5 & 0.4 & 92 & 5539 & $21.98 \times 10^{-2}$ \\
4 & 15000 & 52.8 & 48.4 & 3.8 & 0.7 & 92 & 7254 & $28.78 \times 10^{-2}$ \\
\hline
\end{tabular}

aConversion or yield in mol \%; ${ }^{b S}$ (selectivity) in percent toward PMPs; ${ }^{C}$ TON (turnover number) $=\left[\%\right.$ PMPs $\times\left(\right.$ Oct/Ru)]/100; ${ }^{d}$ TOF (turnover frequency) $=$ TON/time in $\mathrm{s}$. 
they all decreased, while the TON and TOF increased. The SMPs and IPs did not follow a specific trend while the selectivity remained the same, i.e., $92 \%$, at all the concentrations.

\section{${ }^{1} \mathrm{H}$ NMR investigation of precatalyst $\mathbf{7}$ and $\mathbf{5 d}$}

Proton nuclear magnetic resonance spectrometry $\left({ }^{1} \mathrm{H} N \mathrm{NR}\right)$ is a powerful tool to study ruthenium alkylidene complexes and was used to study 1-octene metathesis in the presence of $\mathbf{1}$ and $\mathbf{2}$ $[10,21,22]$. The conversion of the benzylidene, $[\mathrm{Ru}]=\mathrm{CHPh}$, to the heptylidene, $[\mathrm{Ru}]=\mathrm{CHC}_{6} \mathrm{H}_{13}$, and methylidene, $[\mathrm{Ru}]=\mathrm{CH}_{2}$, (where $[\mathrm{Ru}]=\mathrm{RuL}_{2} \mathrm{Cl}_{2}$ ) could be clearly distinguished using the carbene- $\mathrm{H}_{\alpha}$ signals; they appeared as a singlet, triplet and singlet in the $\delta 18.5-20.2 \mathrm{ppm}$ region, respectively. We also investigated $5 \mathbf{a}$ and observed five carbene- $\mathrm{H}_{\alpha}$ signals attributing three to the alkylidene species when the pyridinyl-alcoholato ligand was in the "closed" (coordinated) position; $\delta_{\mathrm{CHPh}}$ $18.05 \mathrm{ppm}, \delta_{\mathrm{CHHx}} 16.71 \mathrm{ppm}$ and $\delta \mathrm{CHH} 16.08 \mathrm{ppm}$ [10]. The other two was attributed to the benzylidene $\left(\delta_{\mathrm{CHPh}} 19.48 \mathrm{ppm}\right)$ and methylidene $\left(\delta_{\mathrm{CH}} 19.76 \mathrm{ppm}\right)$ species in the "open" (uncoordinated) position with the uncoordinated heptylidene signal not appearing probably due to the fast reaction of this species. Four signals at $\delta 9.48 \mathrm{ppm}$ (for the coordinated ligand), $9.05 \mathrm{ppm}, 9.22 \mathrm{ppm}$, and $9.71 \mathrm{ppm}$ attributed to the $\mathrm{H}_{\alpha}$ signals of the pyridine ring were also observed. The latter three signals overlapped too much to be useful.

We performed a ${ }^{1} \mathrm{H}$ NMR investigation of the metathesis of 1-octene by precatalyst 7 in the temperature region $60-90{ }^{\circ} \mathrm{C}$ in order to gain some insight into the reaction mechanism. The carbene- $\mathrm{H}_{\alpha}{ }^{1} \mathrm{H}$ NMR signals at $90{ }^{\circ} \mathrm{C}$ over a period of $345 \mathrm{~min}$ are presented in Figure 12. Three signals attributed to the benzylidene ( $\delta 17.33 \mathrm{ppm}$, singlet), heptylidene $(\delta 16.85 \mathrm{ppm}$, triplet) and methylidene ( $\delta 15.68 \mathrm{ppm})$ were observed. A small signal at $\delta 16.66 \mathrm{ppm}$ appeared at $270 \mathrm{~min}$ and was not assigned (inter alia multiplicity not discernable). A different development of carbene signals over time is observed than what was reported before for 5a [10], i.e., the methylidene signal starts to appear at $12 \mathrm{~min}$ while the heptylidene signal only starts to appear at $165 \mathrm{~min}$. The benzylidene signal rapidly declines after $194 \mathrm{~min}$ and is not observed at $345 \mathrm{~min}$. No clear indication of an "open" or "closed" complex was observed, so it assumed that the signals represent the "closed" species. It can be concluded that the alkylidene species of the pyridinyl-alcoholato Grubbs 2-type precatalysts are quite stable at high temperatures explaining the activity of these precatalyst at high temperatures and the slow rate of disappearance/formation of these signals confirms the longer lifetimes observed in the catalytic reactions.

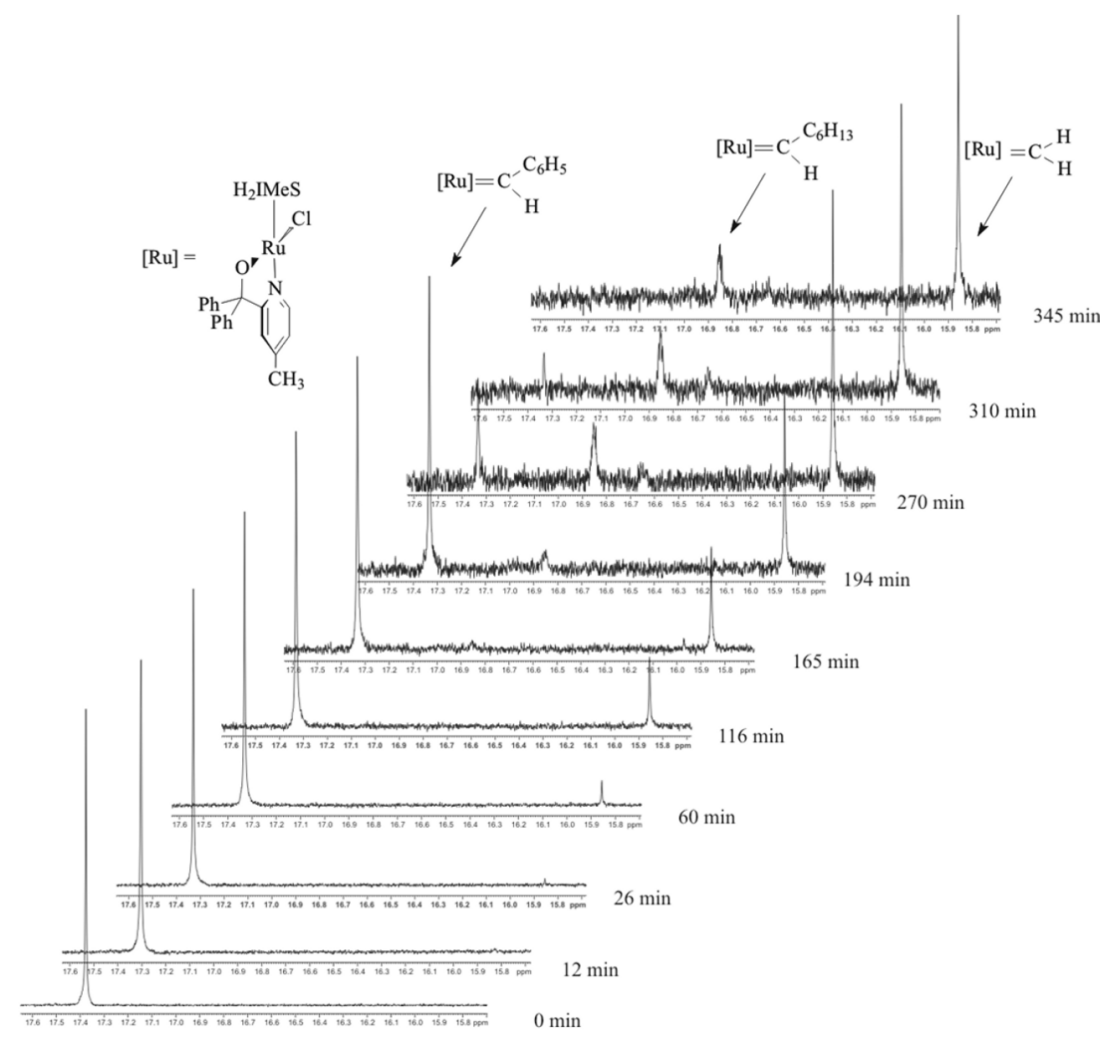

Figure 12: ${ }^{1} \mathrm{H}$ NMR spectra of the carbene- $\mathrm{H}_{\alpha}$ region at different time intervals of the 1 -octene/7 reaction mixture in toluene- $d_{8}$ at $90{ }^{\circ} \mathrm{C}$. 
The $\mathrm{H}_{\alpha}$ pyridine ring ${ }^{1} \mathrm{H}$ NMR signals at $90{ }^{\circ} \mathrm{C}$ at $345 \mathrm{~min}$ are presented in Figure 13. Five $\mathrm{H}_{\alpha}$ signals of the pyridine ring that are not observed at the beginning of the reaction were observed at $\delta 9.57 \mathrm{ppm}$ (doublet), $\delta 9.22 \mathrm{ppm}$ (doublet), $\delta 9.08 \mathrm{ppm}$ (unknown multiplicity), $\delta 8.91 \mathrm{ppm}$ (doublet) and $\delta 8.85 \mathrm{ppm}$ (doublet). The signal at $\delta 9.70 \mathrm{ppm}$ (singlet) was the only signal observed at the beginning of the reaction. These signals is probably due to the "open" and "closed" pyridinyl-alcoholato ligands of alkylidene species and a possible assignment is shown in Figure 13. Further research is required to gain a comprehensive understanding of the operation of the active species of the pyridinyl-alcoholato ruthenium alkylidene precatalysts.

\section{Effect of solvent on 1-octene metathesis using precatalyst 7}

Because toluene- $d_{8}$ was used in the ${ }^{1} \mathrm{H}$ NMR study it was decided to investigate if toluene as solvent has any effect on the 1 -octene metathesis reaction using precatalyst 7 . Results of this investigation are presented in Table 8 .

An increase in SMPs formation is the only difference that was observed when toluene was used as solvent with an $8.9 \%$ in- crease at $420 \mathrm{~min}$. This affected the other performance indicators, i.e., PMPs, S, TON and TOF; lower values than the neat reactions were obtained. The results suggest that no significant solvent effect appears to exist .However, the increase in SMPs (associated with an increase in IPs) indicates decomposition of the precatalyst to active isomerisation species, probably metal hydride species. In our NMR study no indication of the existence of metal hydride species was found.

\section{Conclusion}

The aim of our research is to control the $\mathrm{Ru}-\mathrm{N}$ bond strength of the bidentate hemilabile pyridinyl-alcoholato ligands in precatalyst $\mathbf{5 d}$ in an attempt to synthesise a precatalyst with high performance for linear alkene metathesis at high temperatures. To reach this aim, we synthesised ruthenium alkylidene precatalysts by substituting one of the hydrogens of the pyridine ring of the bidentate pyridinyl-alcoholato ligand by $\mathrm{Me}$ and $\mathrm{OMe}$ groups. We synthesised the 3-, 4-, and 5-methyl and 3-methoxysubstituted 5d precatalysts. The catalytic activity, selectivity and stability results of the Me- and OMe-substituted $\mathbf{5 d}$ precatalysts, in 1-octene metathesis, showed promising results at high temperatures. The high stability, very good activity, selectivity, TON and TOF of the four precatalysts, at high temperatures,

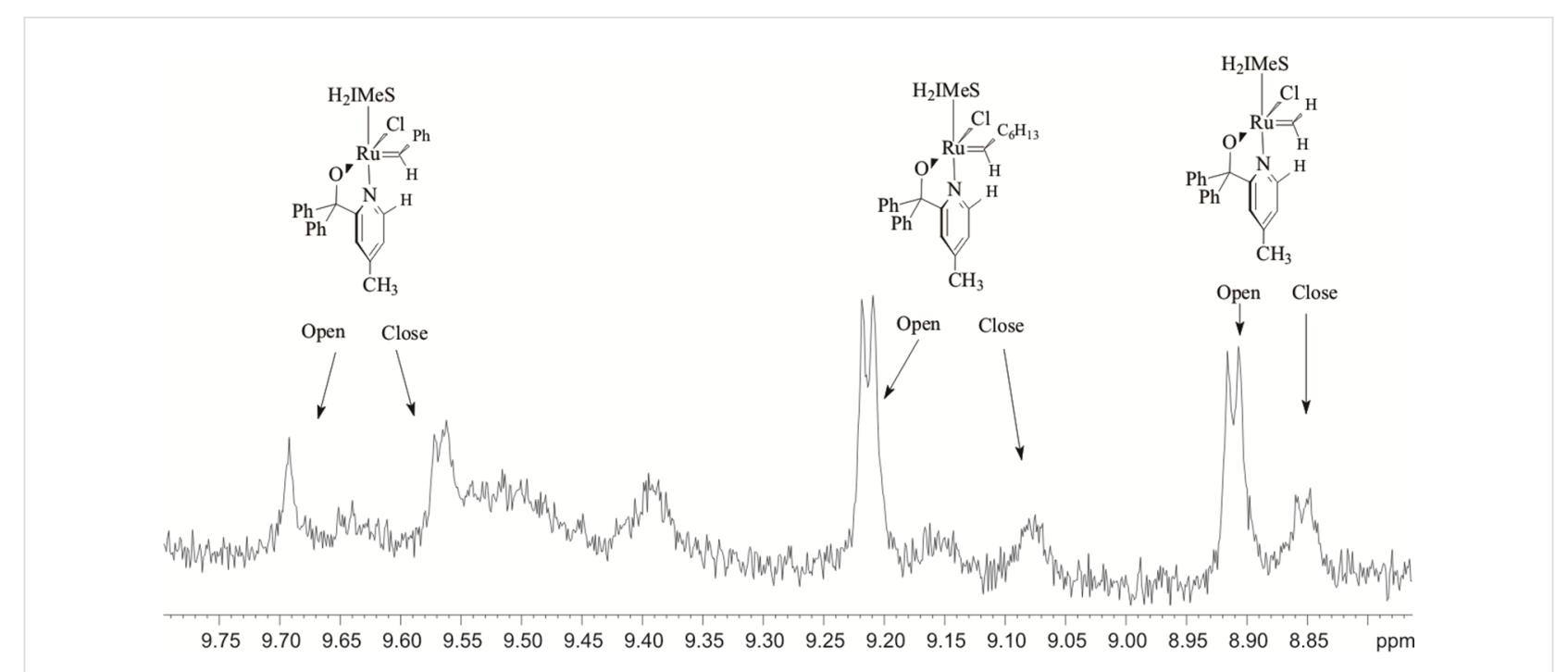

Figure 13: ${ }^{1} \mathrm{H}$ NMR spectra of the $\mathrm{H}_{\alpha}$ region of the pyridine ring of the 1 -octene/7 reaction mixture in toluene- $d_{8}$ at $90{ }^{\circ} \mathrm{C}$ at 345 min.

\begin{tabular}{|c|c|c|c|c|c|c|c|c|}
\hline Entry & Solvent & Conv. ${ }^{a}$ & $\mathrm{PMPs}^{\mathrm{a}}$ & SMPsa & $\mathrm{IPs}^{\mathrm{a}}$ & $\mathrm{S}^{b}$ & $\mathrm{TON}^{\mathrm{C}}$ & TOF $^{\mathrm{d}}$ \\
\hline 1 & neat & 81.4 & 72.4 & 8.0 & 1.0 & 89 & 6516 & $25.86 \times 10^{-2}$ \\
\hline 2 & toluene $e^{\mathrm{e}}$ & 79.8 & 61.8 & 16.9 & 1.2 & 77 & 5564 & $22.08 \times 10^{-2}$ \\
\hline
\end{tabular}

aConversion or yield in mol \%; bS (selectivity) in percent toward PMPs; ${ }^{\circ}$ TON (turnover number) $=[\% P M P s \times(O c t / R u)] / 100 ;{ }^{d} T O F(t u r n o v e r$ frequency) $=$ TON/time in $\mathrm{s} ;{ }^{e} V_{\text {toluene }}=4 \mathrm{~mL}$. 
proved that the hemilability of the bidentate hemilabile pyridinyl alcoholato ligand can be influenced by monosubstitution on the pyridinyl moiety. A Ru/1-octene precatalyst concentration of $1: 9000$ and $80{ }^{\circ} \mathrm{C}$ were found to be the best reaction conditions for the precatalysts. Although 8 performed better than the rest of the precatalysts at $80{ }^{\circ} \mathrm{C}, 7$ showed the best performance in the other temperatures under investigation. ${ }^{1} \mathrm{H}$ NMR spectrometry was used to investigate precatalyst 7 and the active alkylidene species, i.e., benzylidene, heptylidene and methylidene, were observed. NMR evidence of the hemilabile nature of these precatalysts was found in the $\mathrm{H}_{\alpha}$ region of the pyridine ring of the pyridinyl alcoholato ligand.

\section{Experimental}

\section{Instruments and reagents}

${ }^{1}$ H NMR (600 MHz) spectra were obtained using a Bruker Ultrashield Plus 600 Avance III spectrometer.

GC/FID: The progress of the metathesis reactions was followed on an Agilent 6890 gas chromatograph equipped with an Agilent 7683 auto sampler, HP-5 5\% phenyl methyl siloxane capillary column and a flame ionisation detector (FID). The following general GC settings were used: Column: HP-5, $30.0 \mathrm{~m} \times 320 \mu \mathrm{m} \times 0.25 \mu \mathrm{m}$, nominal; detector: FID at $250^{\circ} \mathrm{C}$; $\mathrm{H}_{2}$ flow rate: $40 \mathrm{~mL} / \mathrm{min}$ at $20^{\circ} \mathrm{C}$; air flow rate: $450 \mathrm{~mL} / \mathrm{min}$ at $20{ }^{\circ} \mathrm{C}$; inlet temperature: $200{ }^{\circ} \mathrm{C}, 60.6 \mathrm{kPa} ; \mathrm{N}_{2}$ carrier gas flow rate: $45 \mathrm{~mL} / \mathrm{min}$ at $20{ }^{\circ} \mathrm{C}$; injection volume: $2 \mu \mathrm{L}$ (auto injection); syringe size $10.0 \mu \mathrm{L}$; split ratio: 50.4 :1; split flow $94.3 \mathrm{~mL} / \mathrm{min}$; oven programming: $60{ }^{\circ} \mathrm{C}$ for $5 \mathrm{~min}$; 60 to $110^{\circ} \mathrm{C}$ at $25^{\circ} \mathrm{C} / \mathrm{min} ; 110^{\circ} \mathrm{C}$ hold for $10 \mathrm{~min} ; 110$ to $290{ }^{\circ} \mathrm{C}$ at $25^{\circ} \mathrm{C} / \mathrm{min} ; 290$ to $300^{\circ} \mathrm{C}$ at $25^{\circ} \mathrm{C}$ for $5 \mathrm{~min}$.

GC/MSD analyses was performed on an Agilent 6890 gas chromatograph equipped with an Agilent 7683B autosampler, HP-5 capillary column and an Agilent 5973 mass selective detector (MSD). The oven programme was used with either a two-minute solvent delay or no solvent delay. Helium was used as carrier gas with a $1.5 \mathrm{~mL} / \mathrm{min}$ flow rate at $20{ }^{\circ} \mathrm{C}$. The following general GC settings were used: Column: HP-5, $30.0 \mathrm{~m} \times 320 \mu \mathrm{m} \times 0.25 \mu \mathrm{m}$; Split ratio: 0.1:1; Split flow: $0.1 \mathrm{~mL} / \mathrm{min}$; Inlet: $250^{\circ} \mathrm{C}, 16.6 \mathrm{kPa}$; Injection volume: $0.2 \mu \mathrm{L}$; Detector: 50-550 Dalton mass range; scan speed of 2.94 seconds per decade; oven programming: $60^{\circ} \mathrm{C}$ (hold time $2 \mathrm{~min}$ ); 60 to $110^{\circ} \mathrm{C}$ at $25^{\circ} \mathrm{C} / \mathrm{min} ; 110^{\circ} \mathrm{C}$ (hold time $10 \mathrm{~min}$ ); 110 to $290{ }^{\circ} \mathrm{C}$ at $25^{\circ} \mathrm{C} / \mathrm{min}$ (hold time $16 \mathrm{~min}$ ).

Reagents: 2-Bromo-3-methylpyridine (95\%), 2-bromo-4methylpyridine (97\%), 2-bromo-5-methylpyridine (98\%), 2-bromo-3-methoxypyridine (97\%), $n$-BuLi (2.5 M in hexane), benzophenone (99\%), 2- $N, N$-dimethylaminoethanol ( $\geq 99.5 \%$ ), Grubbs 2 (2) (97\%), 1-octene (99\% GC), nonane (reagent plus
99\%) and toluene (99\%) were purchased from Sigma-Aldrich. Toluene- $d_{8}(99.5 \%)$ was purchased from MERCK and tertbutyl hydrogen peroxide (80\%) from Riedel-de Haen. Diethyl ether and THF were dried over $\mathrm{Na}$ in the presence of benzophenone. Pentane was distilled over $\mathrm{CaH}_{2}$ in an inert atmosphere before using as solvent. 2-N,N-Dimethylaminoethanol and $n$-hexane were dried over molecular sieves ( $4 \AA$ ) and kept under nitrogen before use. Gas-tight Hamilton syringes were used to add reagents and dried solvents to the reactor. Acrodisc Premium $25 \mathrm{~mm}$ syringe filter with $\mathrm{GxF} / 0.45 \mu \mathrm{m}$ GHP membrane (PALL) was used to filter the lithium salt from the precatalyst.

\section{Experimental procedures}

Precatalyst synthesis: The well-established methods of Herrmann et al. [23] and Van Der Schaaf et al. [7] were used to synthesize precatalysts 6-9. This is illustrated in Scheme 2.

Benzylidene chloro(1,3-bis(2,4,6-trimethylphenyl)-2imidazolidinylidene) [1-(3'-methyl-2'-pyridinyl)-1,1diphenylmethanolato]ruthenium (6): Yield $0.422 \mathrm{~g}, 89 \%$, green powder, decomp.: $190{ }^{\circ} \mathrm{C},{ }^{1} \mathrm{H} \mathrm{NMR}\left(600 \mathrm{MHz}, \mathrm{CDCl}_{3}\right) \delta$ $16.89(\mathrm{~s}, 1 \mathrm{H}, \mathrm{H}$ of $\mathrm{Ru}=\mathrm{CHPh}), 9.70(\mathrm{t}, J=3.8 \mathrm{~Hz}, 1 \mathrm{H}, \mathrm{H}-6$ of $\left.\mathrm{C}_{5} \mathrm{H}_{3} \mathrm{~N}\right), 7.24(\mathrm{~m}, 1 \mathrm{H}$, para $\mathrm{H}$ of $\mathrm{Ru}=\mathrm{CHPh}), 7.24(\mathrm{~m}, 2 \mathrm{H}$, meta $\mathrm{H}$ of $\mathrm{Ru}=\mathrm{CHPh}), 7.15(\mathrm{~m}, 2 \mathrm{H}$, ortho $\mathrm{H}$ of $\mathrm{Ph}), 7.05 / 7.28(\mathrm{~m}$, $4 \mathrm{H}$, meta $\mathrm{H}$ of mesityl), $7.00\left(\mathrm{~m}, 1 \mathrm{H}, \mathrm{H}-4\right.$ of $\left.\mathrm{C}_{5} \mathrm{H}_{3} \mathrm{~N}\right), 6.90(\mathrm{~s}$, $2 \mathrm{H}$, para $\mathrm{H}$ of $\mathrm{Ph}), 6.97(\mathrm{~d}, J=3.7 \mathrm{~Hz}, 2 \mathrm{H}$, ortho $\mathrm{H}$ of $\mathrm{Ru}=\mathrm{CHPh}), 6.49\left(\mathrm{~s}, 1 \mathrm{H}, \mathrm{H}-5\right.$ of $\left.\mathrm{C}_{5} \mathrm{H}_{3} \mathrm{~N}\right), 6.75(\mathrm{~s}, 2 \mathrm{H}$, meta $\mathrm{H}$ of $\mathrm{Ph}), 4.01-3.87$ (m, 4H, H of NHC), 2.56/2.18/2.11 (3 $\times \mathrm{s}$, $3 \times 6 \mathrm{H}, \mathrm{H}$ of $6-\mathrm{CH}_{3}$ on mesityl), $1.18\left(\mathrm{~s}, 3 \mathrm{H}, \mathrm{H}\right.$ of $\mathrm{CH}_{3}$ on $\left.\mathrm{C}_{5} \mathrm{H}_{3} \mathrm{~N}\right)$; MALDI-MS $(\mathrm{m} / \mathrm{z}):$ [M] $^{+} 807.2646$ $\left(\mathrm{C}_{47} \mathrm{H}_{48} \mathrm{ClN}_{3} \mathrm{ORu}\right)$; IR (in $\left.\mathrm{cm}^{-1}\right): v(\mathrm{OH}$, moisture $)=3386$, $v(=\mathrm{C}-\mathrm{H})=3054,3018,776, v\left(\mathrm{CH}_{3}\right)=2921,2852,1396$, $v(\mathrm{C}=\mathrm{N})=1604, v(\mathrm{C}=\mathrm{C})=1584-1443, v(\mathrm{C}-\mathrm{N})=1254, v(\mathrm{C}-\mathrm{O})=$ $1157 ;{ }^{13} \mathrm{C}$ NMR $(150 \mathrm{MHz}) \delta 290.4,214.5,169.9,151.2,148.4$, 144.6, 144.4, 139.2, 137.8, 132.4, 128.8, 128.7, 126.8, 126.7, $121.3,93.7,51.2,21.0,19.1,18.8$.

Benzylidene chloro(1,3-bis(2,4,6-trimethylphenyl)-2imidazolidinylidene) [1-(4'-methyl-2' -pyridinyl)-1,1diphenylmethanolato]ruthenium (7): Yield $0.456 \mathrm{~g}, 96 \%$, green powder, decomp.: $190{ }^{\circ} \mathrm{C},{ }^{1} \mathrm{H} \mathrm{NMR}\left(600 \mathrm{MHz}, \mathrm{CDCl}_{3}\right) \delta$ $17.09(\mathrm{~s}, 1 \mathrm{H}, \mathrm{H}$ of $\mathrm{Ru}=\mathrm{CHPh}), 9.42(\mathrm{~d}, J=5.9 \mathrm{~Hz}, 1 \mathrm{H}, \mathrm{H}-6$ of $\left.\mathrm{C}_{5} \mathrm{H}_{3} \mathrm{~N}\right), 7.27\left(\mathrm{~m}, 1 \mathrm{H}, \mathrm{H}-3\right.$ of $\left.\mathrm{C}_{5} \mathrm{H}_{3} \mathrm{~N}\right), 7.27(\mathrm{~m}, 2 \mathrm{H}$, para $\mathrm{H}$ of $\mathrm{Ru}=\mathrm{CHPh}), 7.24(\mathrm{~s}, 2 \mathrm{H}$, meta $\mathrm{H}$ of $\mathrm{Ru}=\mathrm{CHPh}), 7.24 / 7.04(\mathrm{~m}$, $4 \mathrm{H}$, meta $\mathrm{H}$ of mesityl), 7.10 (m, 4H, ortho $\mathrm{H}$ of $\mathrm{Ph}), 6.96(\mathrm{t}$, $J=7.6 \mathrm{~Hz}, 2 \mathrm{H}$, para $\mathrm{H}$ of $\mathrm{Ph}), 6.92(\mathrm{~s}, 2 \mathrm{H}$, ortho $\mathrm{H}$ of $\mathrm{Ru}=\mathrm{CHPh}), 6.76\left(\mathrm{~s}, 1 \mathrm{H}, \mathrm{H}-5\right.$ of $\left.\mathrm{C}_{5} \mathrm{H}_{3} \mathrm{~N}\right), 6.63(\mathrm{~s}, 4 \mathrm{H}$, meta $\mathrm{H}$ of $\mathrm{Ph}), 4.04-3.90(\mathrm{~m}, 4 \mathrm{H}, \mathrm{H}$ of NHC), 2.60/2.25/2.19 $(3 \times \mathrm{s}$, $3 \times 6 \mathrm{H}, \mathrm{H}$ of $6-\mathrm{CH}_{3}$ on mesityl), $1.99\left(\mathrm{~s}, 3 \mathrm{H}, \mathrm{H}\right.$ of $\mathrm{CH}_{3}$ on $\left.\mathrm{C}_{5} \mathrm{H}_{3} \mathrm{~N}\right)$; IR (in $\left.\mathrm{cm}^{-1}\right): v(\mathrm{OH}$, moisture $)=3393, v(=\mathrm{C}-\mathrm{H})=$ 

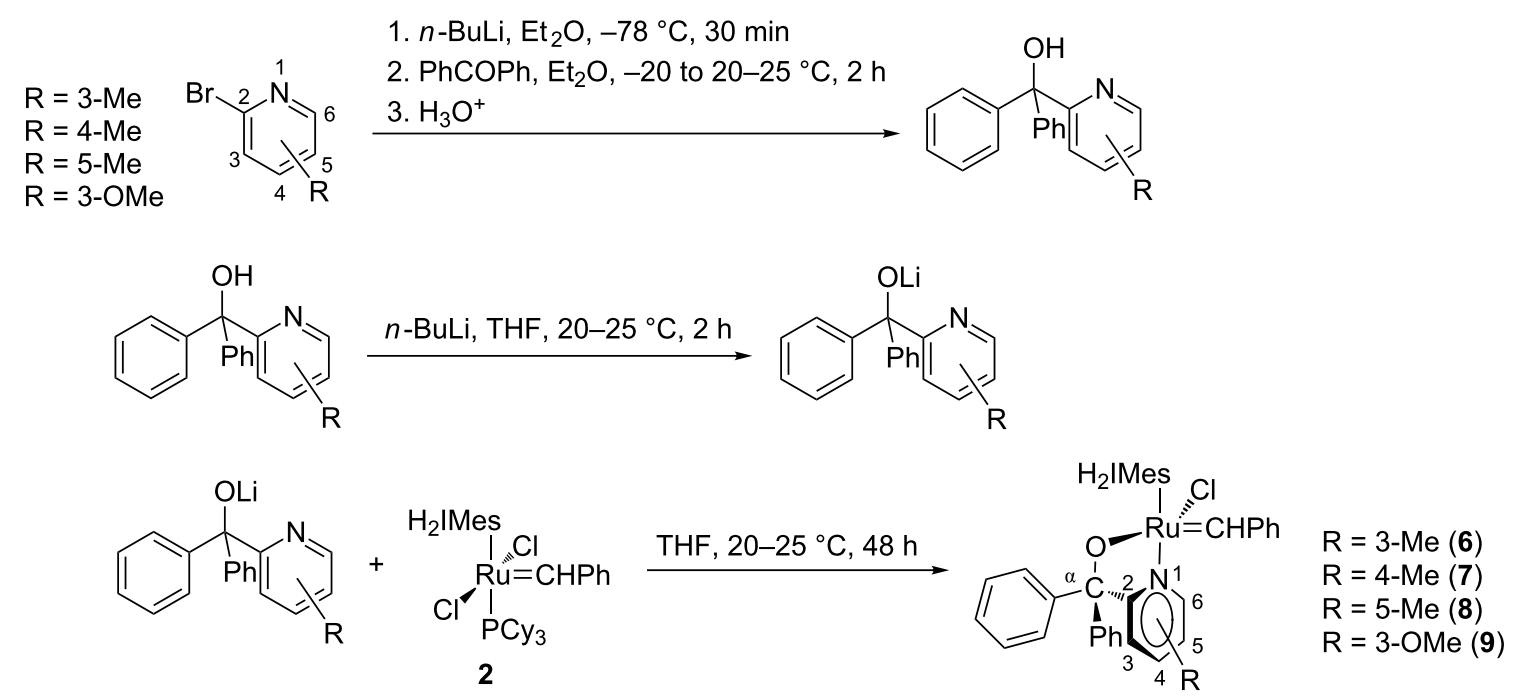

Scheme 2: Synthesis of pyridinyl-alcohol ligands and Grubbs 2-type pyridinyl-alcoholato complexes.

$3052,3018,755, v\left(\mathrm{CH}_{3}\right)=2919,2850,1290, v(\mathrm{C}=\mathrm{N})=1611$, $v(\mathrm{C}=\mathrm{C})=1448-1443, v(\mathrm{C}-\mathrm{N})=1258, v(\mathrm{C}-\mathrm{O})=1248$; ${ }^{13} \mathrm{C}$ NMR $\left(150 \mathrm{MHz}, \mathrm{CDCl}_{3}\right) \delta 291.7,214.7,170.6,151.5$, $149.8,146.2,143.8,139.2,137.8,136.7,129.0,128.5,126.8$, $126.6,122.3,93.0,51.3,21.0,19.1,18.8$.

Benzylidene chloro(1,3-bis(2,4,6-trimethylphenyl)-2imidazolidinylidene)-[1-(5'-methyl-2'-pyridinyl)-1,1diphenylmethanolato]ruthenium (8): Yield $0.304 \mathrm{~g}, 64 \%$, dark-green crystalline powder, decomp.: $125{ }^{\circ} \mathrm{C},{ }^{1} \mathrm{H}$ NMR $\left(600 \mathrm{MHz}, \mathrm{CDCl}_{3}\right) \delta 17.07(\mathrm{~s}, 1 \mathrm{H}, \mathrm{H}$ of $\mathrm{Ru}=\mathrm{CHPh}), 9.37$ (s, $1 \mathrm{H}, \mathrm{H}-6$ of $\left.\mathrm{C}_{5} \mathrm{H}_{3} \mathrm{~N}\right), 7.26(\mathrm{~m}, 1 \mathrm{H}$, para $\mathrm{H}$ of $\mathrm{Ru}-\mathrm{CHPh}), 7.24$ (s, $4 \mathrm{H}$, meta $\mathrm{H}$ of mesityl), $7.14\left(\mathrm{~m}, 1 \mathrm{H}, \mathrm{H}-3\right.$ of $\left.\mathrm{C}_{5} \mathrm{H}_{3} \mathrm{~N}\right), 7.10-7.02$ $(\mathrm{m}, 4 \mathrm{H}$, ortho $\mathrm{H}$ of $\mathrm{Ph}), 6.97(\mathrm{t}, J=7.5 \mathrm{~Hz}, 2 \mathrm{H}$, meta $\mathrm{H}$ of $\mathrm{Ru}=\mathrm{CHPh}), 6.92(\mathrm{~s}, 2 \mathrm{H}$, ortho $\mathrm{H}$ of $\mathrm{Ru}=\mathrm{CHPh}), 6.92(\mathrm{~s}, 1 \mathrm{H}$, $\mathrm{H}-4$ of $\left.\mathrm{C}_{5} \mathrm{H}_{3} \mathrm{~N}\right), 6.75(\mathrm{t}, J=7.6 \mathrm{~Hz}, 2 \mathrm{H}$, para $\mathrm{H}$ of $2 \mathrm{Ph}), 6.68 /$ $6.58(2 \mathrm{~d}, J=7.3 \mathrm{~Hz}, 4 \mathrm{H}$, meta $\mathrm{H}$ of $2 \mathrm{Ph}), 4.00-3.95$ (m, 4H, H of NHC), 2.60/2.26/2.19 (3× s, $3 \times 6 \mathrm{H}, 6-\mathrm{CH}_{3}$ of mesityl), 2.17 (s, $3 \mathrm{H}, \mathrm{H}$ of $\mathrm{CH}_{3}$ on $\left.\mathrm{C}_{5} \mathrm{H}_{3} \mathrm{~N}\right)$; MALDI-MS $(\mathrm{m} / \mathrm{z}):[\mathrm{M}]^{+}$ $807.2660\left(\mathrm{C}_{47} \mathrm{H}_{48} \mathrm{ClN}_{3} \mathrm{ORu}\right)$; IR (in cm $\left.{ }^{-1}\right): v(\mathrm{OH}$, moisture $)=$ 3391, $v(=\mathrm{C}-\mathrm{H})=3055,3020,755, v\left(\mathrm{CH}_{3}\right)=2920,2849,1377$, $v(\mathrm{C}=\mathrm{N})=1605, v(\mathrm{C}=\mathrm{C})=1481-1410, v(\mathrm{C}-\mathrm{N})=1261, v(\mathrm{C}-\mathrm{O})=$ $1163 ;{ }^{13} \mathrm{C} \mathrm{NMR}\left(150 \mathrm{MHz}, \mathrm{CDCl}_{3}\right) \delta 291.2,214.5,168.2$, $151.6,149.9,146.3,143.9,139.2,137.3,134.9,129.0,128.5$, $126.8,126.5,121.7,92.9,51.3,20.9,19.1,18.8$.

Benzylidene chloro(1,3-bis(2,4,6-trimethylphenyl)-2imidazolidinylidene)-[1-(3'-methoxy-2'-pyridinyl)-1,1diphenylmethanolato]ruthenium (9): Yield $0.465 \mathrm{~g}, 96 \%$, green powder, decomp.: $197{ }^{\circ} \mathrm{C},{ }^{1} \mathrm{H}$ NMR $\left(600 \mathrm{MHz}, \mathrm{CDCl}_{3}\right) \delta$ $16.97(\mathrm{~s}, 1 \mathrm{H}, \mathrm{H}$ of $\mathrm{Ru}=\mathrm{CH}), 9.38(\mathrm{~d}, J=5.5 \mathrm{~Hz}, 1 \mathrm{H}, \mathrm{H}-6$ of
$\left.\mathrm{C}_{5} \mathrm{H}_{3} \mathrm{~N}\right), 7.30(\mathrm{~m}, 1 \mathrm{H}$, para $\mathrm{H}$ of $\mathrm{Ru}=\mathrm{CHPh}), 7.29(\mathrm{~m}, 2 \mathrm{H}$, meta $\mathrm{H}$ of $\mathrm{Ru}=\mathrm{CHPh}), 7.25(\mathrm{~m}, 4 \mathrm{H}$, ortho $\mathrm{H}$ of $2 \mathrm{Ph}), 7.16(\mathrm{~m}, 1 \mathrm{H}$, $\mathrm{H}-4$ of $\left.\mathrm{C}_{5} \mathrm{H}_{3} \mathrm{~N}\right), 6.91 / 6.54(\mathrm{~s}, 4 \mathrm{H}$, meta $\mathrm{H}$ of mesityl), $7.04(\mathrm{~m}$, $1 \mathrm{H}, \mathrm{H}-4$ of $\left.\mathrm{C}_{5} \mathrm{H}_{3} \mathrm{~N}\right), 6.99(\mathrm{~m}, 2 \mathrm{H}$, para $\mathrm{H}$ of $2 \mathrm{Ph}), 6.99(\mathrm{~m}, 1 \mathrm{H}$, $\mathrm{H}-5$ of $\left.\mathrm{C}_{5} \mathrm{H}_{3} \mathrm{~N}\right), 6.73(\mathrm{~m}, 4 \mathrm{H}$, meta $\mathrm{H}$ of $2 \mathrm{Ph}), 6.73(\mathrm{~m}, 2 \mathrm{H}$, para $\mathrm{H}$ of $2 \mathrm{Ph}), 6.43(\mathrm{~d}, J=7.7 \mathrm{~Hz}$, ortho $\mathrm{H}$ of $\mathrm{Ru}=\mathrm{CHPh})$, 4.01-3.89 (m, 4H, H of NHC), 2.57/2.19/2.16 (3 × s, $3 \times 6 \mathrm{H}$, 6- $\mathrm{CH}_{3}$ of mesityl), $2.90\left(\mathrm{~s}, 3 \mathrm{H}, \mathrm{H}\right.$ of $\left.\mathrm{OCH}_{3}\right)$; MALDI-MS $(\mathrm{m} / \mathrm{z}):[\mathrm{M}]^{+} 823.2417\left(\mathrm{C}_{47} \mathrm{H}_{48} \mathrm{ClN}_{3} \mathrm{O}_{2} \mathrm{Ru}\right)$; IR $\left(\right.$ in cm $\left.^{-1}\right): v(\mathrm{OH}$, moisture $)=3388 v(=\mathrm{C}-\mathrm{H})=3054,3015,755, v\left(\mathrm{CH}_{3}\right)=2920$, $2848,1316, v(\mathrm{C}=\mathrm{N})=1601, v(\mathrm{C}=\mathrm{C})=1586-1457, v(\mathrm{C}-\mathrm{N})=$ $1258, v(\mathrm{C}-\mathrm{O})=1230 ;{ }^{13} \mathrm{C} \mathrm{NMR}\left(150 \mathrm{MHz}, \mathrm{CDCl}_{3}\right) \delta 290.5$, 214.5, 162.9, 151.5, 151.4, 149.1, 142.3, 139.2, 137.3, 137.2, 129.0, 128.6, 126.8, 122.1, 93.6, 55.4, 51.3, 20.9, 19.1, 18.8 .

Metathesis reactions: The metathesis reactions were carried out in $5 \mathrm{~mL}$ small-scale glass reactors. The reactor containing a small magnetic bar was flushed with nitrogen and an appropriate amount of precatalyst added by weighing. Once again, the contents of the reactor were carefully flushed with nitrogen and the reactor was sealed. The sealed reactor was placed in an aluminium block on a magnetic stirrer. The temperature was set to the desired temperature and allowed to stabilise prior to the reactor being placed in the block. The temperature was regulated throughout the reaction using a temperature controller fitted with a thermocouple. After one minute of heating nonane $(0.25 \mathrm{~mL})$ was added via gastight syringe $(1 \mathrm{~mL})$ as an internal standard, followed by the addition of 1 -octene $(5 \mathrm{~mL})$ via gastight syringe $(5 \mathrm{~mL})$. Samples $(0.1 \mathrm{~mL})$ were withdrawn at time intervals for ca. $520 \mathrm{~min}$ with a gastight syringe $(1 \mathrm{~mL})$, transferred to a GC vial $(1 \mathrm{~mL})$, quenched with toluene 
$(0.3 \mathrm{~mL})$ and tert-butyl hydrogen peroxide ( 2 drops), and then injected into a GC/FID by auto sampler. The metathesis reaction was terminated after 1440 minutes and analysed by GC/FID. Some samples were also analysed by GC/MSD. Each experiment was repeated at least three times.

${ }^{1} \mathrm{H}$ NMR investigation of metathesis reaction: An NMR tube was placed in a Schlenk tube, evacuated with a vacuum pump and then flushed with a stream of argon. The same procedure was repeated and then $12 \mathrm{mg}(0.015 \mathrm{mmol})$ of precatalyst 7 was added to the NMR tube. Once again, the contents of the NMR tube were flushed with argon and toluene- $d_{8}(0.65 \mathrm{~mL})$ added. The catalyst was dissolved by shaking the contents and 1-octene $(0.1 \mathrm{~mL}, 0.64 \mathrm{mmol})$ added immediately before putting the tube in the spectrometer for temperature ranges $30-50{ }^{\circ} \mathrm{C} .{ }^{1} \mathrm{H} \mathrm{NMR}$ spectra were recorded at 5-6 minute intervals for 5-8.5 h. For temperature ranges $60-90{ }^{\circ} \mathrm{C},{ }^{1} \mathrm{H}$ NMR of the precatalyst was done alone before adding the 1 -octene. The precatalyst $(11.5 \mathrm{mg}, 0.014 \mathrm{mmol})$ and anthracene $(5.2 \mathrm{mg}, 0.03 \mathrm{mmol})$ were mixed in the metathesis reaction where anthracene was used as an internal standard.

\section{Computational details}

Geometry optimisation: Geometry optimisation of the precatalysts was done using the DFT module $\mathrm{DMol}^{3}$ of Materials Studio 6.1. The generalized gradient approximation (GGA) with a double numerical basis set and a p-function (DNP) was used. The exchange correlation functional PW91 was investigated. All electrons were treated explicitly and the net charge of all the structures was set to zero. Energies were calculated with frequencies using coarse-grained parallelisation in order to avoid optimised structures with negative frequencies.

Atomic charge calculation: Total electron density was calculated with fine grid resolution, $0.15 \AA$ grid interval and $3.0 \AA$ border. Mulliken atomic charges of Ru were calculated from population analysis and total electron density.

Ru-atom bond length measurement: All bond lengths were measured from the optimised complexes with $\alpha, \alpha$-diphenyl(monosubstituted-pyridin-2-yl)alcoholato ligands.

Hardware: 1. Personal computer (HP); (Windows 7 Enterprise (C) 2009 Microsoft Service Pack 1, Intel ${ }^{\circledR}$ Core $^{\mathrm{TM}}$ i5-2450M CPU@2.50 GHz, 2.50 GHz; 64-bit operating system).

2. HPC: 336 CPU Cluster with $1 \times$ Master Node: (HP BL460C G6 - 2 Quad Core 2.93 GHz, 16 GB RAM, 2146 GB HDD), $40 \times$ Compute Nodes: (HP BL460C G6 - 2 Quad Core $2.93 \mathrm{GHz}, 16$ GB RAM, 2146 GB HDD, ProLiant BL2 x 220c G5, HP BL460C G1), $1 \times 3$ TB HP EVA 4400 SAN and 1x HP
BL460C G6 Storage Server, Operating system on compute nodes: Scientific Linux SL release 5.3, Cluster operating system: Rocks 5.2 - Scientific Linux SL release 5.3.

\section{Acknowledgements}

The financial support of the North-West University (NWU) and the South African Department of Science and Technology (DST)-National Research Foundation (NRF) Centre of Excellence in Catalysis ( $\mathrm{c}^{*}$ change) towards this research is hereby gratefully acknowledged. Opinions expressed and conclusions arrived at, are those of the authors and are not necessarily to be attributed to the NWU or $\mathrm{c}^{*}$ change.

\section{ORCID ${ }^{\circledR}$ iDs}

Tegene T. Tole - https://orcid.org/0000-0002-5858-9239

Johan H. L. Jordaan - https://orcid.org/0000-0002-8134-6753

Hermanus C. M. Vosloo - https://orcid.org/0000-0002-5879-323X

\section{References}

1. Grubbs, R. H.; Wenzel, A. G.; O'Leary, D. J.; Khosravi, E., Eds. Handbook of Metathesis, 2nd ed.; Wiley-VCH Verlag $\mathrm{GmbH}$ : Weinheim, Germany, 2015. doi:10.1002/9783527674107

2. Grela, K., Ed. Olefin Metathesis: Theory and Practice; Wiley-VCH: Weinheim, Germany, 2014. doi:10.1002/9781118711613

3. Slugovc, C.; Burtscher, D.; Stelzer, F.; Mereiter, K. Organometallics 2005, 24, 2255-2258. doi:10.1021/om050141f

4. Monsaert, S.; Vila, A. L.; Drozdzak, R.; Van Der Voort, P.; Verpoort, F. Chem. Soc. Rev. 2009, 38, 3360-3372. doi:10.1039/b902345n

5. Tole, T.; Jordaan, J.; Vosloo, H. Molecules 2018, 23, 896. doi:10.3390/molecules23040896

6. van der Schaaf, P. A.; Abbenhuis, R. A. T. M.; Grove, D. M.; Smeets, W. J. J.; Spek, A. L.; van Koten, G.

J. Chem. Soc., Chem. Commun. 1993, 504-506. doi:10.1039/c39930000504

7. Van Der Schaaf, P. A.; Mühlebach, A.; Hafner, A.; Kolly, R. Heterocyclyl ligand containing ruthenium and osmium catalysts. U.S. Patent 6,417,363 B1, July 9, 2002.

8. Wijkens, P.; Jastrzebski, J. T. B. H.; van der Schaaf, P. A.; Kolly, R.; Hafner, A.; van Koten, G. Org. Lett. 2000, 2, 1621-1624. doi:10.1021/ol0059100

9. Denk, K.; Fridgen, J.; Herrmann, W. A. Adv. Synth. Catal. 2002, 344, 666-670.

doi:10.1002/1615-4169(200208)344:6/7<666::aid-adsc666>3.0.co;2-0

10. Jordaan, M.; Vosloo, H. C. M. Adv. Synth. Catal. 2007, 349, 184-192. doi:10.1002/adsc.200600474

11. van der Gryp, P.; Barnard, A.; Cronje, J.-P.; de Vlieger, D.; Marx, S.; Vosloo, H. C. M. J. Membr. Sci. 2010, 353, 70-77. doi:10.1016/j.memsci.2010.02.032

12. du Toit, J. I.; Jordaan, M.; Huijsmans, C. A. A.; Jordaan, J. H. L.; van Sittert, C. G. C. E.; Vosloo, H. C. M. Molecules 2014, 19, 5522-5537. doi:10.3390/molecules19055522

13. du Toit, J. I.; van der Gryp, P.; Loock, M. M.; Tole, T. T.; Marx, S.; Jordaan, J. H. L.; Vosloo, H. C. M. Catal. Today 2016, 275, 191-200. doi:10.1016/j.cattod.2015.12.004

14. Tole, T. T.; du Toit, J. I.; van Sittert, C. G. C. E.; Jordaan, J. H. L.; Vosloo, H. C. M. Catalysts 2017, 7, 22. doi:10.3390/catal7010022 
15. Slugovc, C.; Wappel, J. Olefin Metathesis. WIPO/PCT Patent WO2013/029079 A1, March 7, 2013.

16. Schachner, J. A.; Cabrera, J.; Padilla, R.; Fischer, C.; van der Schaaf, P. A.; Pretot, R.; Rominger, F.; Limbach, M. ACS Catal. 2011, 1, 872-876. doi:10.1021/cs2002109

17. Cabrera, J.; Padilla, R.; Bru, M.; Lindner, R.; Kageyama, T.; Wilckens, K.; Balof, S. L.; Schanz, H.-J.; Dehn, R.; Teles, J. H.; Deuerlein, S.; Müller, K.; Rominger, F.; Limbach, M. Chem. - Eur. J. 2012, 18, 14717-14724. doi:10.1002/chem.201202248

18. Cabrera, J.; Padilla, R.; Dehn, R.; Deuerlein, S.; Gułajski, Ł.; Chomiszczak, E.; Teles, J. H.; Limbach, M.; Grela, K. Adv. Synth. Catal. 2012, 354, 1043-1051. doi:10.1002/adsc.201100863

19. Getty, K.; Delgado-Jaime, M. U.; Kennepohl, P. J. Am. Chem. Soc. 2007, 129, 15774-15776. doi:10.1021/ja0747674

20. Ritter, T.; Hejl, A.; Wenzel, A. G.; Funk, T. W.; Grubbs, R. H. Organometallics 2006, 25, 5740-5745. doi:10.1021/om060520o

21. Ulman, M.; Grubbs, R. H. Organometallics 1998, 17, 2484-2489. doi:10.1021/om9710172

22. Jordaan, M.; van Helden, P.; van Sittert, C. G. C. E.; Vosloo, H. C. M. J. Mol. Catal. A: Chem. 2006, 254, 145-154. doi:10.1016/j.molcata.2006.03.022

23. Herrmann, W. A.; Lobmaier, G. M.; Priermeier, T.; Mattner, M. R.; Scharbert, B. J. Mol. Catal. A: Chem. 1997, 117, 455-469. doi:10.1016/s1381-1169(96)00381-0

\section{License and Terms}

This is an Open Access article under the terms of the Creative Commons Attribution License (http://creativecommons.org/licenses/by/4.0). Please note that the reuse, redistribution and reproduction in particular requires that the authors and source are credited.

The license is subject to the Beilstein Journal of Organic Chemistry terms and conditions:

(https://www.beilstein-journals.org/bjoc)

The definitive version of this article is the electronic one which can be found at: $\underline{\text { doi: } 10.3762 / \text { bjoc. } 15.19}$ 